Andrews University

Digital Commons @ Andrews University

Master's Theses

Graduate Research

1959

\title{
A Supervisory and Remedial Reading Program in a Seventh-day Adventist Elementary School
}

Dorothy Nelson Moore

Andrews University

Follow this and additional works at: https://digitalcommons.andrews.edu/theses

Part of the Elementary Education Commons

\section{Recommended Citation}

Moore, Dorothy Nelson, "A Supervisory and Remedial Reading Program in a Seventh-day Adventist Elementary School" (1959). Master's Theses. 147.

https://dx.doi.org/10.32597/theses/147

https://digitalcommons.andrews.edu/theses/147

This Thesis is brought to you for free and open access by the Graduate Research at Digital Commons @ Andrews University. It has been accepted for inclusion in Master's Theses by an authorized administrator of Digital Commons @ Andrews University. For more information, please contact repository@andrews.edu. 
A SUPERVISORX AND RESDTAL READTNO modran

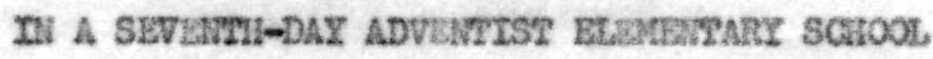

A Thests

Presented to

the Faculty of the school of Craduate studies

Dopartinent of solucation

Potanac Univarsity

In Partlal FuleLurwont

of the Requareatats for the Dogree

Master of Axts

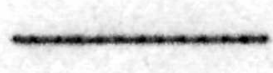

by

Dorothy Nelson Noore

June $\mathbf{1 9 5 9}$ 
This dissertation, written under the direction of the Chairman of the candidate's Guidance Committee and approved by all members of the Committee, has been presented to and accepted by the faculty of the School of Graduate Studies in partial fulfillment of the requirements for the Master of Arts degree.

Date .... Jupe. 1959. . . . . .

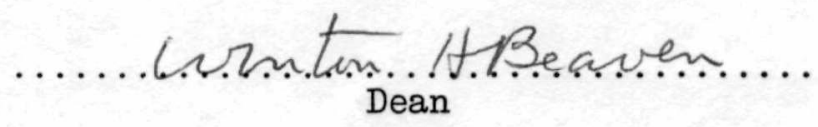

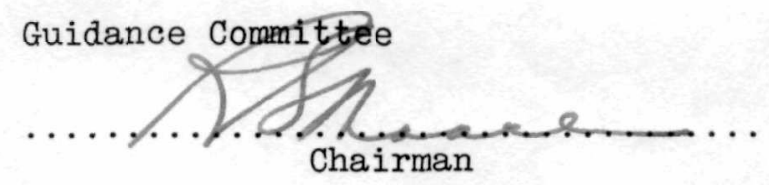

Kernich Pithman...

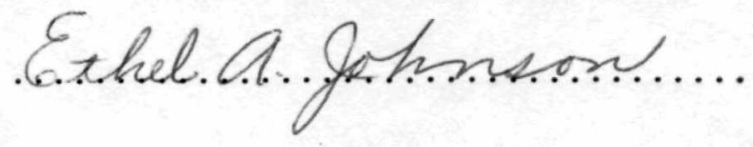


Thazs of comrans

CHAPER

PAos

I. TuE Fostik, ITS ruport, Neñons, SCOPR, Am

grantzatron .................... 1

The problen ..................... 1

Iraportance of the stucy ............... 2

Hothods usod ..................... 2

scope of the problen ................. 3

Deflnitions of torns used .............. 3

Supervisor ....................... 3

Renodsal readlng teacher ............... 3

Actual grade placanent ............... 3

Organleation of the study ............. 4

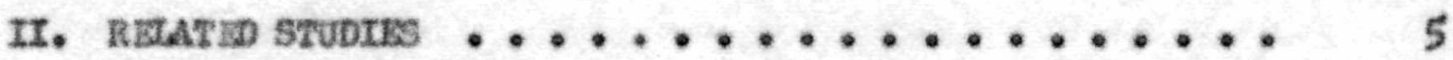

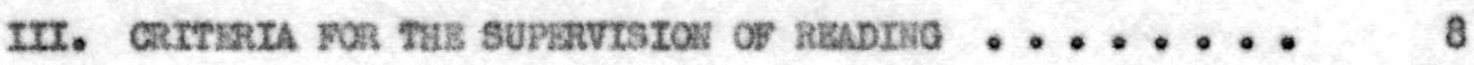

What are the-broad objectives of the reading program

In a Christian school? ............... 8

What are aome of the procedures which tho eupervisor may

uoe to carry out these objectives? .........

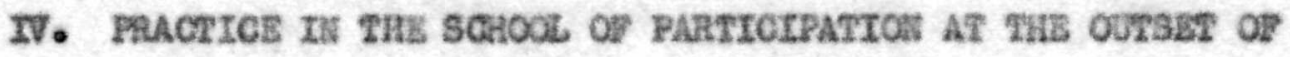

The proJger ...................... 18

Postlve practlcos .................. 18

Undestrable practleos and conditions ......... 19 


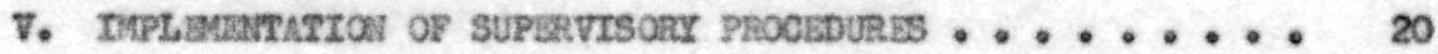

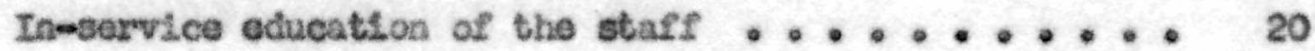

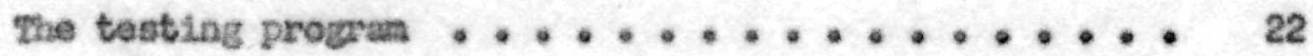
Publie and parent ralations ............... 23 Haterlals of Instuction ................. 24 Smphasts on readiag in all phases of the school

program IMbrary books :.+...................... 25 Halp for talchers

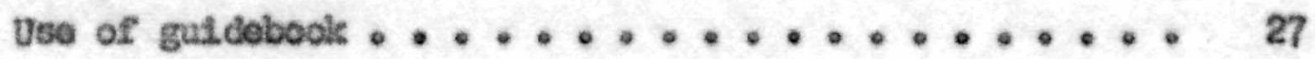

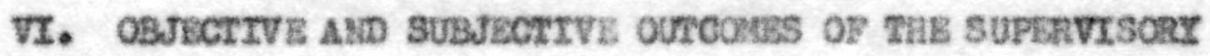

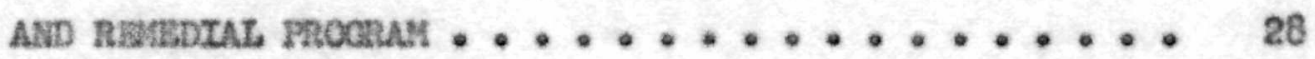
Objectlve outeones ................... 28 Gain coupared to normal expoctation ......... 28 Reacing achievenent compared to actual grade placensent ..................... 30 Resding achlevonont compared to reading capacity . . 32 Aotual. Brade placonant in corparlsone ........ 32 gain in ronedial classes ............... 35 AudLtory discepinination .............. 35

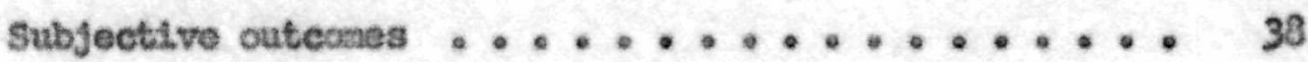
Parent-teacher relationshtps ............. 38 Changes in etasaroon assignuent ........... 38 
CMAP2:AR

Parontal sallafactions ........... 39

Teacher motitvation ................. 39

Traportance of student attitude......... 40

Special case no. $2 \ldots \ldots \ldots \ldots$

spoctal caes no, $2 \ldots \ldots \ldots \ldots . . \ldots . . . \ldots 4$

Spectal ease no. $3 \ldots \ldots \ldots \ldots$

tree of the alble and spirltual outeonos ..... 44

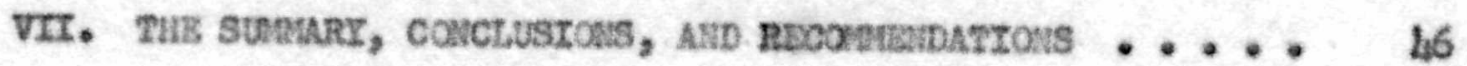

The sxraary ....................... 47

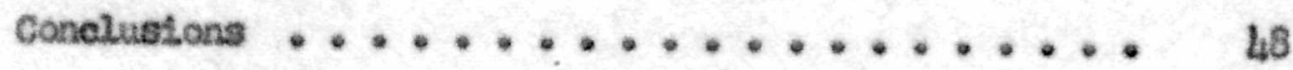

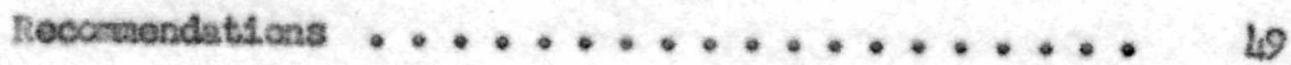

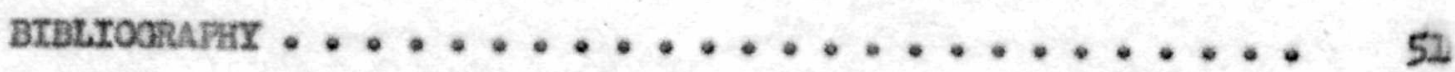

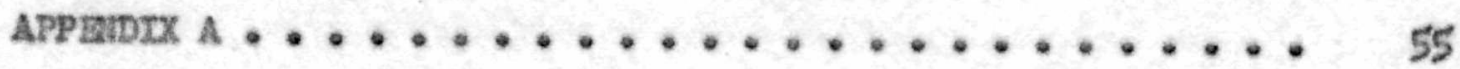

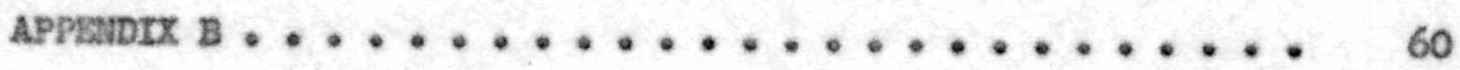


LIST OF FIOURES

FIOURE

PAOE

1. GAIN IN RBADINO ACHIBVEMBEI COMPARBD TO NORMAL BXPRCTATION $\ldots \ldots \ldots \ldots$

2. AVRRAB READINO ACIIBVEMENT BY ORADES CONPARED TO ACTUAL ORADB PLACEREM 31

3. PERCENAOS OR ALL (280) STUDINTS IN GRADES THRES TO SIX READING UP TO THEIR CAPACITY AT THE BAD OF SEPTEMBER COIPARED TO THOSE RERDINO UP TO CAPACITY AI FHE ERD OF APRII ...........

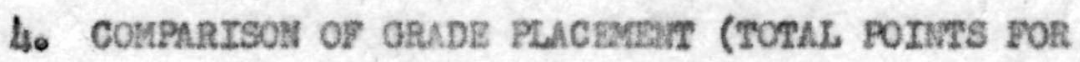
BACH ORADE) BETWEAT LAST OP SEPTEESR, 1958, AND LAST OP APRIL, 1959, SHOWINO SUMARY OF THE STVDEMTS II EACH CLASS WHO ARE BEION WORAL ACHIBVIgasm $\ldots \ldots \ldots \ldots \ldots \ldots \ldots \ldots$ 34

5. GAIN IN READINO ACHIBVEREN IN REOULAR CLaBsroons COMPAREA TO OAIN IN REMBDAL CLASSES ACCORDTNG TO arADES ....................... 36

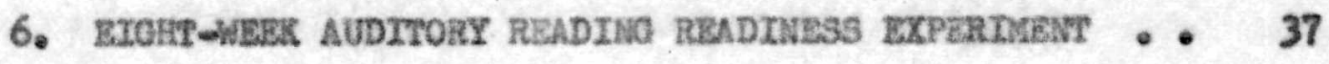


superviaton and renodial. Instruction, and (3) to stucy tho effect of such a supervisory and rosodial progran on tho sosding accorplishnonts of the firet aix grades in the John Ifevins Androws school.

Importence of the atudy. It is well understood by teechers at alnost orory lovol that baste reading ablilto is essontial to all othor loarning, and that meh of the eurvent educational, alerras stene from the fact that rary students do not loarn to read ofrelelently in the elonontary school. Also becauso of the religlous oryhasts in the Soventh-day Aeventist schools, lt is necossary that the studente achleve faclusty in the reseling of the BAble and the books of the church. Anv device, therefore, which oan Inorense the quallty of the over-all rsading progran is vorthy of thoughteru concldoration and investleation so that the most efficient moans ma bo employed in other denoninational schools。

Methode used. Strudy was given to the bate philosophy of Chrtethan education of the Seventh-day Advontist sohool araten ae set forth

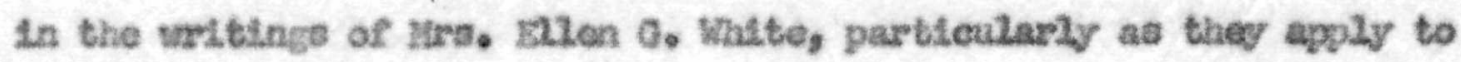
roading.

Study vas aleo given to goneral mothode of ouporviston as well as roading supervistion as set forth by experts in the flold of readinge Intenotve partiefpation and observation in the regular clasorocas of the John trovine Andreus school, Including actual partetino teaching In noot of the elassarooss, gave opportunity to evaluste clasaroca procodures and to corpare then with the best of current proctice as found in educational istorature. 
As noarly as poustble, the best methods of superviaton and renedIal Instruction, Indivioual and group, were pat into practice in the John tievins Andrens school, and both objective and subjective roaults were obtatnod. This Ineluciod an all-achool toetine progran as voli is sroguent tosting of ranodirl reading students.

Scope of the puabless. Study was tintted to the axporviaton of reading and ronedtal instruotion in the 23 rot atx grades of nis and the results obtainod in the school your $1953-59$.

\section{DErrurruons of Trmes USED}

Supervisor. For lack of a nore exprobenstve title, the term "oupervisor" was used to designate the euthor of this study when vrorleing in a oupervisory expactity.

Ronodial reading tescher. In the oane way, the terns vrenedial. roading tescher" or "monding toscher" vere used to dentgnate the author when worleling in the senedial phase of the readine procrats.

Actual grade plecenent. The sctual grade postition of a chidd or a class at a gtven time is called tho actual, crado plscenont, and is deternined by the proportion of the school your which has elapeod. In Chapter vrs the term is used to indleate the grade postlion of the various alasses at the time the teats wore givon. For exarple, at the time of the firat serlos of teats st the end of Septonber, the actual grade placeneat of anl elaseos wae 21 above their grade or 2.1 for second gradere, 3.2 for thind graders, h.2 for fourth gradors, ote. There 
are tan fourwoek months in the school yoar. Whus ono-tanth is equal to one school manth. At the tire of the 1ost sorles of leats at the and of AprL1, the elghth worth, the actwal grede pleowent for all classes wae .8 above their grade or 2.8 for socond gradors, 3.8 for thare gradars, 4.8 for fourth graders, and so forth. Aotval grade placonont mat aot be confused whth woasures of achsevenento

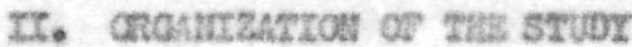

The study is dividod Into saven chapters. Chapter I states the

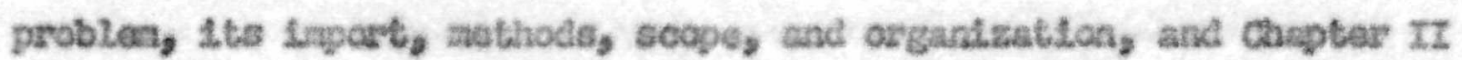
brieng rovious ralated atudies in rending superviaton. Corteris based on eurrent prectsice as found in educationel 14terature 1nelutIng the writiags on Clulstian eluestion by lars. Elien a. Whate are presonted in Chapter ITT. Chapter IV Indtestes practieos in the school of particlpation at the outeot of the profect.

Chapter $\mathrm{V}$ incheates the maner in which the mapervisor attenpted. to carry out tho objeotives of the resding progren in the John lievina Androve olenantary school scoording to the crltarla Listed in Bection B of Cheptor Irt. Both objective and aubjective rogults of thits progran aro givon in Chapter VI. The PLral chapter Ineluded tha surnary, conclustone, and genural, reconanondatsons for luproventent in the achool of participation and in Sovonthinday Advonttat schoole at large. 


\section{CHAPras II}

\section{RISATUD STUDTES}

In $2955 \mathrm{Dr}$. Rudole Jesch in the boat soller, thy Johngy Cantt

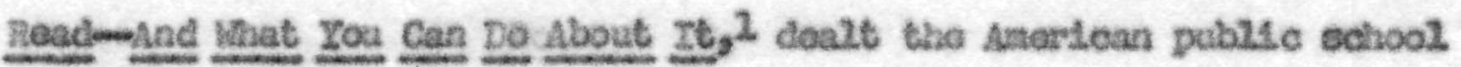
systen a hard blow, bringling much publie crltielas and aroubling conatderable controvoray rogarding cortsin of the presont aystons of taschIng ohlidren to read. Though undoubtodhy unfalr in his accusations, and unsetentifle in his suggested curc-all for the problen, his indiotnent probably did no lasting hasa and perhaps oone roal good in that it eaused educators to re-axantne objectives and removaluate nethods, Improving tharevor nocosaary and rocogntalng that more could bo done to bottor the Instructilonal progras in roading. Since then there has beon a stendy stroan of publithed matorlal regarding different phases of the tesching of roading which has groatiy contributed to those who aro soekding for sonothing botter.

The ultirate responstbixty for the ouccess of the roading progras of any school soens to be placed wpon the prinetpal.

Raublngar axys:

As never boforo, the principal mat assuto a postition of educational leaderohip anong his faculty and provide a laybtoday gustance nooded by the inergerioneod or the inatogantoly propared teacher. This soans tiat the prineipal, mast give

1 Rudale Fosch, Why Jahnny Can't Read-mind Hat You Can Do

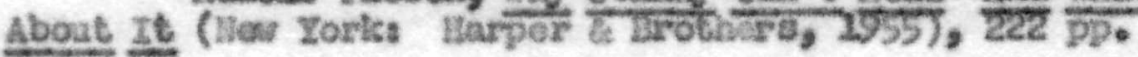


priortty to ins responatbility as supervisor and advieor to his teachers. 2

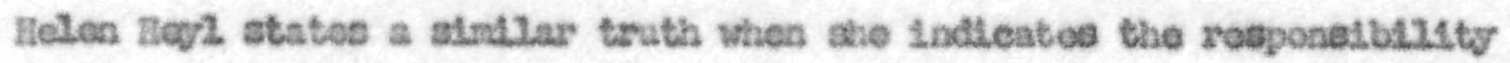
of the prinotpal and the supervioor to halp the individual toscher to estimate the value of his clnssrocen procodures and the results of his worlc, and to asstat hin in planning improvenents, ${ }^{3}$

One of tho noat arphastsod princtples in teaching ronding appeara to be that of miting the proper allowance for individual dufferences. anott A. Dotte discusaes the problens ereated by treatlng all cilldren aceording to the "avorage," Indleating that odueatore way go dan-

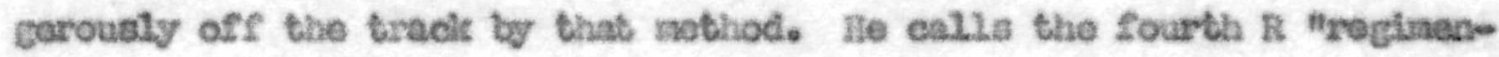
tation in the clasaroca, " and auggests Instedd throe typos of groupling for reading purposes-one for basle reading, one for speolfle neods, and one for interost areas, woling books on cheferent levols but in the sane interost aroa. 4

In a discusotion of asceptional children in the regular elasarock, D2. Jack W. atreh elves a number of spectele suggestlone for enzlehIng the progran of glfted ehilerea. He statos that even though they

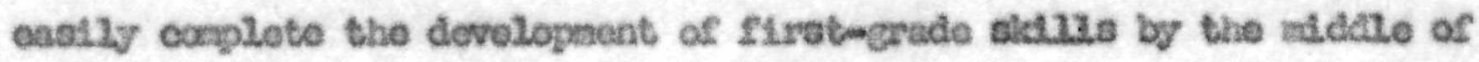
tho tarn, they thould not be hold back nor confinod to reading widoly In axplenentary matorlal, ingortant as $4 \mathrm{t}$ 15. Rathor, they should

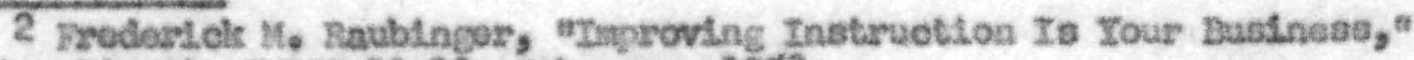
Bluentson D1ecat, xxIIr $121-23$, Fobruary, 2950.

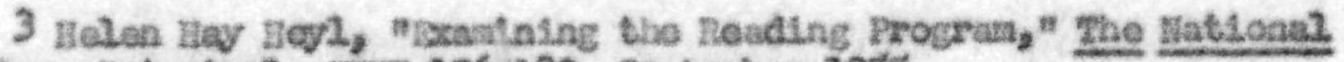
Benentary Princtpai, xoxv 2176 2.60, soptenbor 1955 .

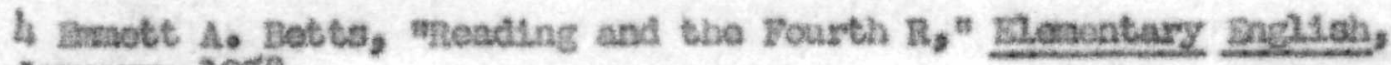
18-25, January, 1950. 
be Introducod to socond-or thiml-grade reading alctus in the basic rouders as soon se roadiness and necosalthy for the stclus bocone evident, evon if the ciuld is staul in the first grade, 5 The Joplin plan, whtch has rocelvod eonstelorable publect ty puts all fourth, flsth, and stath graders into honogenoous groupe for roading rather than atwly grouplag vithin a single olasaroom, and has mot with rather phenomanal success.6 A stmllar cosporimant vith tho third and fourth grade chtldren in the Ronald sehool in sastile, WashIngton, was roportod as heving nore advantagas than dtascivantages, though data wore not sufficient to prove 1ts worth atatiatiealiy as yot.7

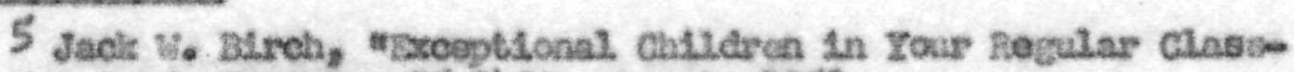
rocas," The Grude Feaches, 75:34fe., Narch, 1950.

6 roul Tunioy, "Johrny Can read in Joglin," The Reader's DAgest, (January, 1058), 1.12-64.

7 sathor slsonnord Carlson, and Joyee Horthrup, man seporinont In Groupling Puptla for Instruction in Meading," The Hationsl Denentary Prlnctpen, 2xxvi53-57, Septertber, 1955. 


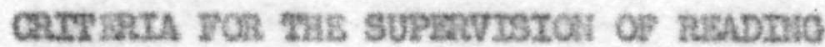

A wide varioty of current literature, as well as the writings on Chrlotian education by Mrs, Elon G. Shite has boen studiod in order (2) to establiah a aot of broad objectives for the reading progran in the Sevonth-day Adventist church school, and (2) to doternine sone of the ways in which these objectives nay be carrled out through superviston. In the presentation of those criteria, each has been substantiated by one or more authoritative references. These are in no way Intended to be comprehonatvo, but have been selected sa the nost pertinent in the 11 torature extanined. In this connection, then, taro questions should bo considered?

A. What are the broad objeotives of the zreading progrom in a Christian school?

2. To propare the chlld for the higher school in heaven and for aervice in this world.

You are laboring for time and for eternity, molding the minds of your students for ontrance into the highor school. Every right principle, every truth loarnod in an earthly school, will advance us Just that much in the hosvenily school. 1

The thought of the etornal. IIfo should bo woven lato all to which the Carletian sets his hand. If the work porfornod is

${ }^{2}$ ation G. White, Gounsels to parents and Feachers, D. $208 \mathrm{f}$. 
agricultural or mochantesl in 1ts naturo, st nay stilu be ofter the pattom of the hoaveniy. 2

It should be the teacher's alm to prepare cvery youth under has care to be a blessing to the world. 3

Children are a horitage from the Lord, and they are to bo trainod for Itis sorviece 4

The tenchers in the hone and the teachera in the sohool. thould have a synathatic underetanding of one another'a sork. They should labor together harrontously, Inbued wrlth the saso misutonary splmt, stelving togethor to bonefit the chlidron physies IIy, mentrily, and apirituelly, and to develop charactors that w112 stand the toat of ternptation.5

2. To tesch chtldren to read well orally with proper ueo of the voleo.

Volce culture shosid be taught in the ronding elnseg and in other elasses the tencher should Instat that tho studants speate distsinotiy, and use words which exprese thols thougtsts clear2y and foretibiy. Students atould be taught to use thols abdontral nuscles in broathing and spoukting. Fnts will malko the tonea nore fun and olear:

In reacting or in rocitation the pronunctation ahould be cleas. A nasul tone or an unguthily attstude should be at once comoctod. Any lack of diotinctases should bo maslood as dafoctivo. Thay, have allowod thenselves to form the habit of speeteling in a thick,

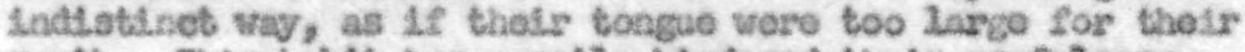
mouth. This hablt has greatiy hindered their usefulnoss.

It Is essentsal that atudonts bo tratnod to Fond in a clasr dlatinet tone. We have boon painod as wo have attonded conferonce mootings, tract soclety mootings, and meetings of ivarious klnds, where roporte wore roed in an alnost inaudible volce, or in a bestintine mannor or in a wurraed tone, One hale the
2 rbide, pe 58.
3 posdes po 96.
4 Ibsd., D. 14.3.
5 Ibsdes po 1570
6 Thides D. 216.
${ }^{7}$ rosede; po 239 . 


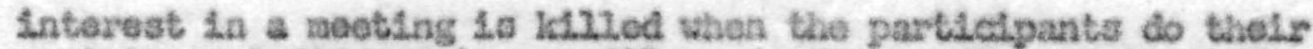
part in an inderforvat, spiritless fachlon. Thoy should learn to opoak in such a way that they can odtfy those who klaten. Lot evoryone connected wh th misstenary work quallsy husolf to speak in a clasr, attractive way, onunetating his worda perfectly.

Orel readisg ehould be a sharing procuse where the rasder's purposo 13 to entertain his 14 stenors, to give thes supplenontasy Inforration, or to prosent evidence in proving a polnt. Thus reading textbooks aloud in poutine fashlon destroys the true purpose of caral reading, stimulates halting and mechantesl. porformanco, and encourages a dilalise for reading on the part of the inopt orel roader hisasolf-cribarrassed at his atumbling pes-

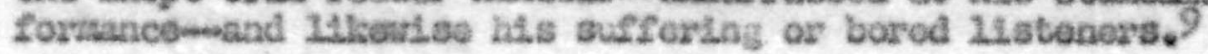

3. To develog the chlld's Intereat in and destro for good road-

Ing, ospectally of the BAble and the books of the chasch.

If the alind is sot to the taak of studying tho BLble, the understanding w111 atrongthon and the reasoning faculties w111 1mprove. Undor the study of tho Scriptures the mind oxpands and beocnss more ovenly balancod than if oecupled in obtaining information from bodis that have no connection with the BLble. 10

Above all other books, the word of coel must be our studv, the great teatbook, tho baots of all education; and our children aro to bo educatod in the truths found thoreting irrospoctive of provious habsta and custors. 11.

The BAble should not be brought Into our schools to be sandvichod botweon infidelity. Cod's vord must be made the groundwork and subjeet mattor of education, 12

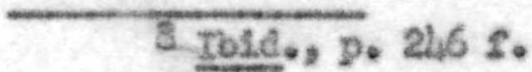

9 unidred A. Dawron, The Role of oral Readinc in Sohool and tife Aetivities," plaxentary Paphs sh, 30-37, January, 1958.

$20 \mathrm{kmite}$, Counsels to Perents and Fesehars, D. 452.

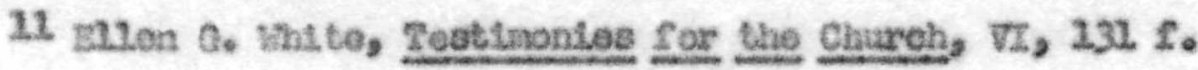

12 white, Counsoles to Parente and Feachers, po 16. 
The poalinlst doclares, mwen Thou saldst, seek yo ty face; my heart sald unto Thee, Thy face, Lord, will I soek." PS. 27:B, The whole of this poalm should rind a piace in the reading and spelling lessons of the school. The twentylol ghth, twenty-ninth, and seventy-aighth paalns tell of the rloh blossings beotowed by God upon Elis people, and of their poor returns for all mis benoP1ts, The of ghty-rirst psalm explatns why traral was scattered,they forgot cod, as the churches in our land are forgetting Him todisy. Consider also the el ghty minth, minetieth, ninety-first, ninety-second, and nlnety-third psaln.

These things were vritten for our admonition, upos whom the ends of the world are cone; and should they not be studted in our schools? The word of cod contalns Instructive lessons, givon in roproof, in warning, in encouragensent, and in rich pronlses. Would not such food as this be meat in due season to the youth?23

Let students put to the stretci thoir montal faculties, that they may comprehend the forty-flfth chapter of Isalah. Such chapters as this should be brought into our schools as a valuable study.14,

The Holy Seriptures were the essential study in the schools of the prophets, and thoy should hold the first place in evory educational system: for the foundation of all right edueation is a lenowledge of cod. Used as a textbook in our schools, the Btble w:11 do for mind and morals what canaot be done by books of sclenco and phllosophy. As a book to discipline and strengthen the intellect, to engoble, purify, and refine the character, it 1s without a rival. 15

There is another class of booles-love storles and frivalous, exciting tales-which are a curse to everyone who reads them, even though tho author may attach a good moral. Orten roligious

23 rbid., pe $457 \mathrm{ff}$.

14 Tbid.o, p. 455.

15 Tbid., p. 422. 
staterante are woven all through theso books; but in nost cases Satan Is but clothod in angel robos to docolve and allure the unsueptetous. The practico of story reading 18 ane of the means erployed by Satan to dostroy souls. It produces a false, un-

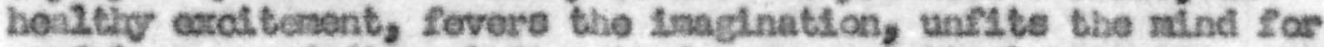

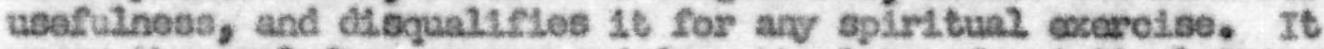
woans the sous fron pravor and fron tho lowo of spistbual thinge. 16

4. To tosch the chlid to understand, organtzo, and appratse what he roads, applying the truthe of the Btble to his ow 11 fe.

If [the teachor] should not rost satlafied with the presentstlon of any subject unthl tho studant understands the princtiplo 4nvolvod, percolvos 1ts truth, and 18 able to state clearly what be has loarnod. 1 ?

It Is the worlt of true education to . . tratn the jouth, be thinicers, and not mere reflectors of othes men's thought. 18

Toachere ahould Lead atudents to thinik and cloarly to undorstand the truth for theraselvos. It is not enough for the tescher to explatn, or for the atudant to bellove; Inquiry mast be atraliened, and the student sust be dross out to otate the truth in his on langusge, thus malcting it oviciont that he sees its force and ravires the applícation. . . Thlo my be a slos proceses but lt ls of nore value than ruahling over ingortant subjects without due conalderation.19

5. To teach the aldizis the chld seeds to bring success at increasing levels of otfrleulty in all subjocts of the curriculues.

The toacher should carefully study the disposition and character of his puplls, that he mav adapt his tenching to thetr pecultar noode. 20
16 Ible, p. 1340
17 whitte, sclucation, p. 234.
28 rbsed., pe 27.
19 whste, Testirontes to the Church, VI, 254.
20 Whito, Councels, p. 231. 
In order to do effective study, the interost of the chlld must be onilsted. Espocially by the one who has to do with

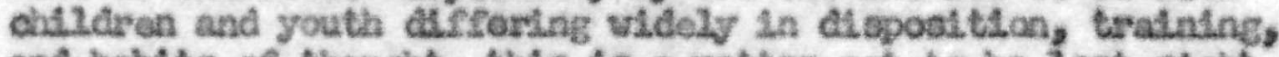
and pabits of thought, this is a matter not to be lost sight of. 21

Those vino would makte a success in the olucation of the youth must talce then as they arv, not as they ought to be, nor as they ut11. be when they cane from under thody tratninge 22 .

The tescher ahould constantly atn at simplifelty and effeetivenoss. Ile should teach largely by 111ustratton, and even in dealing with olcer puphis should be correful to mate evory explanation platn and cloar. 23

Feachers may Learn a Loston fros the experienco of the famer who placed the food for his eheop in a erib so high that the young of the Mock conld not roach 1t. Iome teachers prosent the truth to theis atudente in a stinlas manner. They placo the crib

The ayoton of grading is sonotives a hindrance to the puptits roel progreass. Somo puplis are slou at firet, and the teachor of these youth neede to exterclse great patienee. But those puptis may after a bhort time loarn so rapidy as to abtonith hilh Othors nay appear to be very brilliant, but tine ny ahou that they have blossonod too suddonity; the aviten of conflnins chiletren rigldiy to grades is not wiso. 25

Prinetplee applicable to all loarnores

1. Begin there the learnos is (or a 24ttle bolow that point if you want to bulld up his confldence).

2. Procood at the loarnorts pace (stopplng occastonally to review, ascintlate, and conalolidate paet learning), 26
21 Tolå., D. 183.
22 valte, Caristian Shucation, p. 25.
23 Whste, Counsole to Feachors, po 262.
2h. IOLAC, D. 435 . 25 IoLd., D. 177 .

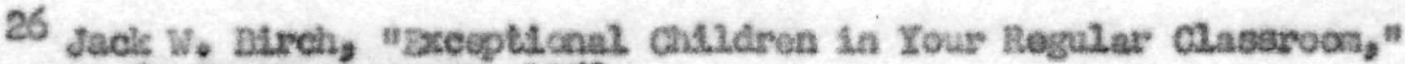
3hse, The Grade Teacior, March, 1958. 
B. What are sone of the proceduros which the supervinor may use to carry out these objectives?

1. The superviear onlil devise varloua noans of luproving the Instructional progran through Inesorvice education of the steff. Barr, Burton, and Brueclener glve a rather conclee outline of deviees avaliable for tratning purposes as followss

A. Vorbal monns of tralning tenchers in service inelucting (1) the Individual conforences (2) the group conferences (3) builetins, handboolks, and other printed alds; (4) diroctod roedings and (5) institutional course work。

B. Directed observation as a means of training toachers in borvice ineluding (1) the directed observation of regular classroon instruction, or (2) difrected obeervation of spectal. denonstrations provided by the supervisor or sone monber of the tenching staff for trainine purposes.

C. Direct contact learning devices ermiloyed in the tratning of teachers in service, including (1) teacher participation in the formulation of instruetional plans and policiess (2) teacher participation in courso-of-study maicing; (3) tetcher participation in the cholee of Instruetlonal materials: textbooice, oupplies, and oguipments (4) teacher particlpation in the formulation of the criteria by vhlch teschine my be ovaluated and ultinately improved, and (5) teachar partictpattion in educational probtenasiving. 27

2. The supervisor will carry out a conststent progran of test1ng, both group and Ind.vidual when necessary, and soo that the results are used intelligontly in grouping chldiren and in solecting material for them:

The H. A. [nontal age] is a good Index of the lovel of roacting

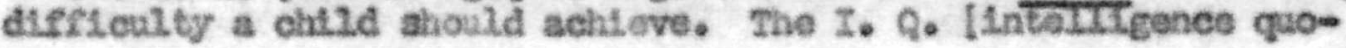

\footnotetext{
27 A. 3. Barr, willean H. Burton, and Leo J. Brueclener, Supervialon, p. $667 \mathrm{f}$.
} 
thant] is a valuablo indicatog of the rate at which a chald should progress in loaming to read.20

3. The supervier vil2 help to interpret the reading progran to the public, eapecially to the parents, and consult with individual. paronts when nocessury.

Ie that not, than, our basic purpose for a progran of interwpretation of roeding-to belp parents discover the fact that we are trying earneatiy to provide a good roading progran, and to halp school people to discover that parants can play a vital role In developtng the roadsing progran if to the plus and work toEother? 29

4. The aupervicor wi11 IInd and prepare matorials to help with the ronodial, cases as well as with the gifted children. Dr. Pawl witty, In discussing the glfted chlld, says that "perhaps the greatest posslbiLity sor anrichnent ties in the fleld of roading $=30$

5. The supervisor will use various meuns to see that "reading is beling exphasized as an all-school, every-tescher, overy-bubject rasponstbilsty: $" 31$

If the only tratning in reating recelved by puptis is of a basal roading type, they vill not be able to read effoctively in other curriculum rielels. It is necessery for teachers to rocognlas pupli noede and develop slctils for this purpose. 32

${ }^{28}$ Jscik U. Birch, Retrieving the Retarded Reader, D. 9.

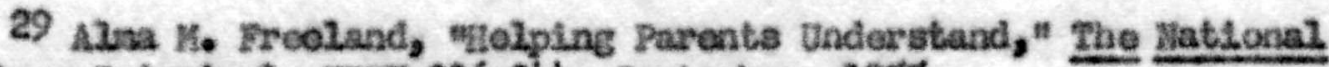
Lanontary Prinelinal, XXxV:236-2hi, Septenber, 1955.

30 Faul A. W1tty, meading for tho Potential Leador and ruture Selontist," The Pation's Schools, 61:57-59, Foburary, 1958.

31 paui A. Uttty, "Johnuy Could nead Better," The Nation's Schools, 61:L0-42, January, 2958:

32 george D. Spache, meading in Vartous burriculus Flolds," The Edacation Digeat, xirI:47-49, Apri1, 1958. 
Instruction in word analyels is of even groater importanee in intermeditate grades than in primary gracles. The carefunly controlled vocabulary that appears in primary rosdere is lergely

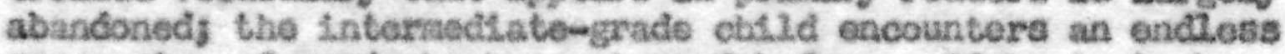
auccession of words he has not road before. If he is to be euccossfu? in rodeng, he must be vary rapld and accurate in word analyala. 33

6. Tho atpervisor w121 help to develop an adsquate and wollorgandzod school libeary as vell as holplng to secure a rich varloty of books for the classrocm, including sets of supplementary roadors both below and above the grade level for esch grade. Thte 1 s one of the ltens strotsed by paul Mtty. 34

7. The readiag suparvisor vill relteve the heavy duthes of the tescher as mach as posstble by encouraging the use of alder cididren to help the younger, by providing spectal renedial help for cortain students when necessary, by providing other rolief for the toacher so that he may have tine for planntng and preparation for his reading claases. Blon G. White counsels that ". . whare the mumber of atudants is large enough, assistants should bo chosen from anong the older ones. Thus Give students will galn an expertenco of great value. 35

8. The supcurvisor wi13 encourege the une of the toscherta manual. or sutdobook, expecially for inexperlencod of Insciequately tratnod teachers.

For all taschors, but particularly fos noweonars in a achool, the dutdobook provides as excollent "coures" in reading nethode-

33 Donald D. Durrell, Igrroving Reading Insturuetton, D. 267.

34 Paul A. Mitty, "Judging the stading Progran," The Hation's Schools, 6l:60-i, April, 1950.

35 white, Coungels to Parants and Feachers, p. 200. 
theory and praetileoma course plrpointed for esch teacher to the spectfle grade level she vorics vith. She takes the "course" under idoal conditions, too, for she his a chance to put the Ideas galnod into imoodiste praetice and see for herrolf hors they work. 36 


\section{CaApren IV}

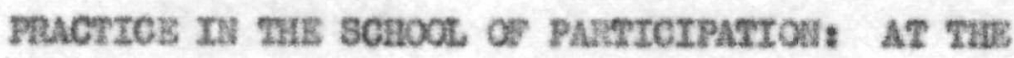

ours or or Tas provecr

Batended obsorvation in the school of partlctpetson ylalded a number of destrable, postlive practicos in the suporviston of the reading program, and a fers which corinitely hinder progress but which are in the process of bolng corrected. For the purposes of this chapter, the posttive prectices w113 be 1istod separately undor (1) those pertaining apectrlestly to supervisory work, and (2) those pertatning more directly to the elassrocn teschor.

I. Poaltive practices.

A. In superviston.

2. An awaraness by the princtpal of her roaponsibility for the suceoss of the reading progran, and an openmindednoss tarard nev ldess.

2. An active in-sorvice tralning prograa for teachers.

3. Proviaton of a roesonably adeguate aupply of $14 \mathrm{~b}$ rary books for supplenentary roeding.

4. The utsirsation of the oldor to help the youncer.

5. An active publio relattons progran through the Hone and Sehool or Parent-'Peacher Assoctation to aogualnt the parents with Instructional, methods. 
6. Organisation of renoctlal classos with a ronodial toweher.

7. A rensonably good testing progrars.

B. Dy the tesching staff.

1. An onthusiastie and cooperative attltude touard the ronedisl. reading progran.

2. A thincare destre to lourn better sothods of teachlng reading.

3. Mte use of experience roading charts in the primary grades.

4. Camplete cooperstion in providing devicos for motivating outstde reading.

II. Undealrable practices and conditlona.

A. Lack of adequate space for a contral 1ibrary.

B. Traditional teaching rethods by sose teschers naking little or no sllowance for Individual differencas. Also lack of thoroughneas in "following through."

C. Apparently inadeguate rosding Inatruction as auch in the atidete and uppor grades.

D. Chsldeowned readors corresponding to erade placenent, hindering some chlldron from being placed where thoy can malse the bost progrese.

E. Iack of sufficlent sote of supplenentary roadors.

7. A feu Inadocquately trained or unaletiled teachers. 


\section{custur V}

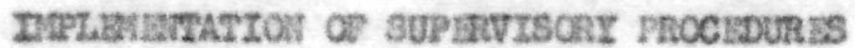

Critorla for earrying out the broad objectives of a reading progran through superviaton are listed in Soction B of Chapter III. The nethods used to carry out these responatbulities are prosented harewith in the sane order ae the basic critorla aro 1isted in Chapter III.

2. In-barvice gducattion of the gtaff. At the beglnning of the school year a forty-flve minuto indevldual conforence was arrangod by the supervisor with each tosches to discuss test results, grouping, readers to be used, and other reading problens. Throughout the yoar there wore nunorous informal convartations whth each teacher regarding methods, toxtbooks, and certaln Indivletual reading problens. Theso were Initlated by the teachers thenselves fully half of the tirte.

In soveral Instancos the supervisor had the opportunity of eubatstuting a ruli day or nore in a elasaroos, and was able to ovaluste at Strst hand the reading accocplibhnonte of the chlldren. A conference w1th the toucher soon afterward provod a very profitable way to further help her in her elaseroon mothods.

The supervisor conducted etudies at four teachers' aeotinge on purposos of teating, renodial mothods, nothods of tenching curricular reading, and ways of allowing for indivldual atfforences, both for the slow and the ghfted child. Two differont teachers' Institutes during the year gave addttional Ideas and notivation for good tesching of 
reading. Dccastonal informal group conferences wore also held to Alscuss problems in cominn. These often tookt place axound the lunch table, on the playground, of In the hall, as well as in the classrocas. Balletins, elipplings, and other portinent material on roading vere either posted on the bullotin board or ctrculated. A number of nes books on reading mothods wore purchasod for the toachers! 14 brary. All toachere vere oncouraged to talce a clase in the teaching of roading given at the noarby Potonac Untvarsity. Tultion was pald by the school, and two were able to Join this class. The atxth grade teacher, assiated by the supervisor, was the University instruetor in this class, so four of the achool stafe had an intenstve refresher elass in ganoral and romedtal reading methods.

At the beginning of the school year the roeding supervisor denonatrated news reading in three different elassroons, indieating the prinelplos of curricular roeding nothods.

stnce it was constdered dealrable to bring in outalie authority to provide an objective point of view, in Junuary Mas Lucy Loclehart, eonsultant fron Wesleyan Undversity in Connecticut, wss called in to bring nor Ideas to the staff. She denonstrated both Lntarmedlate and Iower grade tenching nothods in curricular reading for all teachers to obsarvo. She later spolce to the eroup in an evatuats on assion, efving principles of tescher proparation, explatning hor to develop roading readiness in the entire class, describing mothods of gulding the allent and oral readIng, 11.1ustrating ways of dealing with Individuel differences, and dewonstrating how to stimulate critical talnkling. 
Teseher particlpation was exployod as a devide in all incividual. and group conferences, as well as in the full taschers" meoting, partieularly in the formalation of Instructional plans, eholee of ingtruetional materials, and educational problen-Bolving. Nore could have boen done In the formulation of criterla by which teaching nay be ovaluated and Inproved, although other check 11 ats, including the one in the appendix of this stucty, wore presented to the tesehers.

2. The togtling program. At the beglnning of the school year all eisidren in the first alx grades were tested. First grade children wore given the Nurphy-Durrell Dlagnoatle Roading Readiness Testg 1 second grade children were given the dates Prinary Reading Test, 2 Including word recognition, sentence reading, and paragraph rondings and those in grades three to six were glven Forn A of the Durrell-Sullivan Raading Achlevemant Jest $^{3}$ as we.11 as the Durroll-suluivan Reading Capactty Tost.4 The Capacity Test was a non-reading test ceas gned to moasure a ch1ld's general understanding of vocabulary and factual material. A dufference of one grade or more in the rating between the schlevernent

\footnotetext{
1 EClen A. Murphy, and Donald D. Durrell, Murphy-Durrell Dlagnogtie Resctnose Teat.

2 Arthur I. Cates, Gates Brinary Resding Fest.

3 Donald D. Durrell and Eolon Blair Sullivan, Durroll-Sullivan MeadIns Achiovesent Fest.

A Donald D. Durrall, and Folen B. Sullivan, Burrell-Sullivan roading canacl ty Test.
} 
and eapaelty teat scores Indicatod that the child was not reading up to his ablitty and therefore should have special help.

These test results, along with teacher Judment, vere used as a batsis in grouplang the children in tha classroon, in detarninting the groups needing spectel, rencodial help, and in dectelng what teastboolcs should be used for then.

About six weoks before the end of the sehool year each groug was rotested to check progress made under the oupervisory and renodial prograb. The Rirat grade ehliden were given the dates Prinary Reading Teat, the second grade chlldren were givon the Gates Advanced Prtrary Rending Test, and those in gradee threo to six were gren Form B.of theo Durrell-Suluvan Reading Aehievenent Teat.

3. Public and parent rolations. At two different Hons and School meethgs and at two school board meetings, the supervisor was requasted to explain the testing and reading progran to the parents and board manbors. The response was enthuslastle, and brought a nood of opportanities for individurl consultatios with parents at torse and sohool meetings, by telephone, after school, and in infornal convereathons at gatherings where parents could be coatseted. Ilotes wore occastonsliy sent to parents to keep them Infornod of the progress of their ehlldren, and reta of Rash cards were furntshed to sane who asked to glve their chlieren extra holp at hone.

In certaln Instances, consultatlons were infitiated by the supervisor to help solve problesas. In a typtend case, an oye dirrteuity in a child was suapected, and a telephons call to the mothor brought about an ege 
cxanination, glassos to correct the difficulty, and subsoquent ingrovenent in resdinge

In another case the mother of a nervous elild who was consistently brlnging a nuturtionally neagor lunch, and who was ovidently not gotting sufrielent stoep was contscted. She was vory cooporative when she understood the effect of thite progras on hor chlld. The chald seened to find nov gecurtty and happlness in his consistant2y good lunches thereafter.

On Prot-grade day In Apr11, the supervisos talked to the parents of the chilaren who would be eatering first grade in the fall. She explained the school's plan to provide a good roading progras, and gave When apecirie augestions as to how better to propare thely chuldron for school during the ensuing five asnths.

4. Natarials of Instruction, For the purposes of the renedial Classos I.t wae assuned that the usual asthode had falled and that a net approseh to learnlag was necossary for success, Therefore, the regular textbooks, workbooks, and clasaroon equipmant for the tenciking of reading was avoicled as much as posstble. Instoad of these, a vartaty of spectal anteriale for the ronodial classes were purchasod or prepared by the supervisor. Purchased matorlals ineluded master coples for duplicating phonics and wordeanalyole excorcises on all grado lovels, Doloh's word ganos, 5 ganos fron Phonovloual Aids ${ }^{6}$ and Reasedtel aduestion Canter?
5 See Appandix B.
$6 \underline{\text { rbic. }}$
7 Ibid. 
1a Washington, high Litorest Level worltbooks by the actlors of Iy

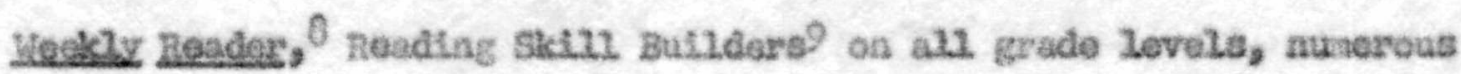
hsgh Lnterest plessure reading books on varlous levilis, and fouy beauthrul large print Btbles. Zencher-nedo satertals Included Wordo, a rootwrord gane, s suffux and profix gatu, a word ending game, and muvorous sots of flash cards for varlous teaching purposes.

For the regular classrooms, several, nes sets of supplementary basal resdors, with accomgarying workbooles when necessary, wore purchased where needed. PLans call for sthll more sets to be adied for the next school yoar.

5. Emphasis on roading in all phasos of the school progran. Whis supervisory responsiblitity was carsled out by moans of the Inpservice tratine progran outlined in section 2 , Including individual and group conference, denonetrations, and talks wt th principal and rogutar tanelers. The whole tone of the school was tuned to the now resding prograst by varLous devices of the princtpal as well as the supervisor.

6. IAbrayy boolss. In addt thon to munoroes Itbrary boolse on hand, a large number of 21 brary books have been purehased this year to bo used In the elassrocns, A seperate, centrul 14brary contatns additlonel booke and reoouroe matertal.

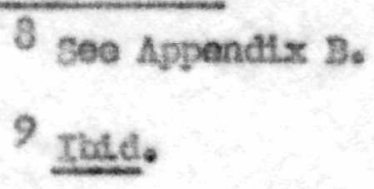


7. Help for teachers. The presonce of an active organisation at the John tlevins Andrews school called "The Teachors of Day After Tanorrou" sponsored by the principal, providod much oxeellent halp for the teachers. There were about thirty girls in this club from the soventh and eighth gracios who gpent fron thirty alnutes to an hour oach day helpling a teacher to whon thos wore asstgnod. In thise time they corrected papers, gave spocial drill to Individuals or groups who needod 1t, of conducted roading proups. Ga the day of the spectal denonstration by Milsa Locitart, the girls took ovor the classroons to free the toachors to watch the denonetration.

within oach clasaroon the Idea of using the more able to holp the Less able was successfully prosoted.

A renodial progran was sot up to care for most of these who tested below grade lovol. A group fron each dnsaroon was glvon spectal instmuction by the supervisor for twenty-rive to thirty minutes each day for four davs a week, excopt for the strth grade chaldren. They roceived one-fourth to one-hale of this anount of special ranodial instruction. This relleved the teacher of responstbilitios she felt for these remedial cases which the dit not have time to fulrint.

In many lnatances, the chlidren who were sont to the ronedial classes wore those who noedod the nost overnall attentlon in thelr onn classroons. Many were the dischipline problons. Therefore, when they were at their spectal reading class, the toacher had a nore 1 doal stwasthon in which to worle whth the renaling groups.

Though not ceactly renodlal in 1ts purpose, one Rrat grade group was givon opectal training in audstory discrinination further to prepare 
then for reading instaruction.

The ronodial, roon tras a snall cornor in the school auditoriura, closod off by folosing doore and equippod with a table and chairs rathor than deskes, a Roor lamp and a bookcase. Sonne of the childron called 1t "our little house," for 1t sooned to give an atnosphere of informal coziness in contrast to the elassroom. Inasureh as the typleal sttuathon had not brought success to the chslidren, it was thought best to adjust envirormont and wathod suffictentiy to provide a now avanue of Iosminge.

The princtpal and oach tescher emphastzed to the childron that nombership in the apectal reading classes was a privilego, and it was so constdered throughout the year by alnost an, concomed. The word "ronodial" was not used in the presonce of the children.

8. Uso of guidobook. AMI tonchers were furnishod with and ancouragod to uve guidobooice for thely basal readers and other printed natomials as helps in teaching curricular reading. In more than one Instance, it was obvious that consclentious uge of these helpe brought about spectelc improvonont in the teaching of reading in the clesarocn and thus botter schievonant by the students. 
Cuprur vt

OBJICTIVE AMD SUBJECTVE OUTCOUIS OF TUS SUPERVISORY

AID RESDTAL ProdraM

This study was necessarily lintted by the fact that no records froe previous years without a supervisory and romedial progran aro avallable for comparison. However, certain results from the testing progran Indlente signifleant gaine in the reading progran of the school. These objective results are 111 ustrated by graghe and charts on the follosing pages.

Other results, though not measurable by tests or other moans, are nevortheloss signiflcant and are roported as part of the outcones of this study.

\section{OBJicrrva OUTComs}

Qain Conpared to Mormal Mepectation

The Durroll-Sullivan Roading Aehlevenent was givan the last of Apri1, 1959 , to 285 chllatren to compare achlevenent with the bogthning test givan the last of September, 1958. In this time of approxdrately seven school months betweon tests it was normaliy expected that the average galn for a elisld in any given grade would be .7 of a grade. This normal coxpectation is Indicated by the rod shaded aros in Flgure 1. Actual increnonts aro Lilustrated in black. It can be seon that all. clasees exceoded this nornal expectation and that the third grade made 


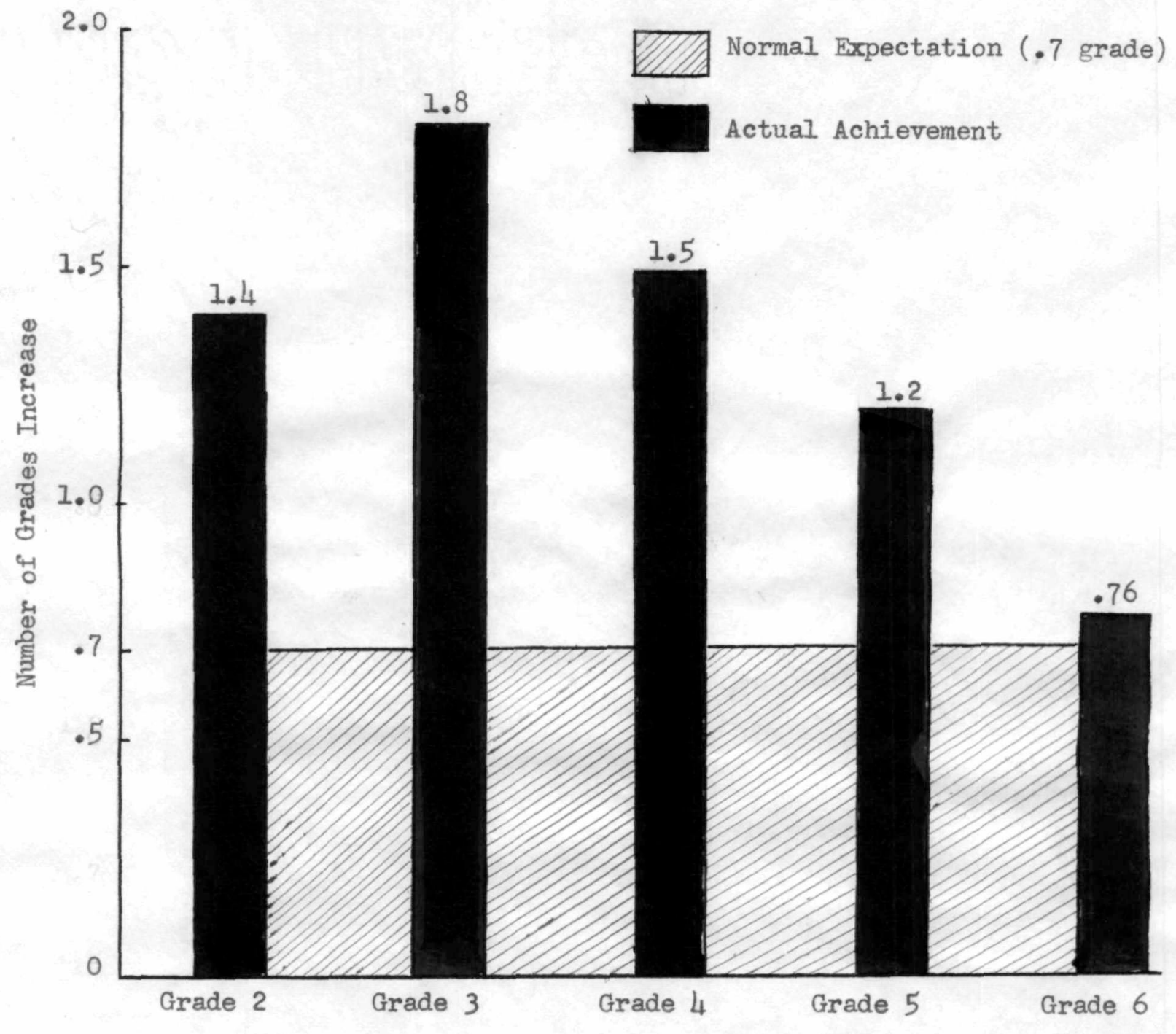

FIGURE 1

GAIN IN READING ACHIEVEMENT

COMPARED TO NORMAL EXPECTATION 
the greatest gain with the socond and fourth grades coning vary elose. Since twenty out of fifty-four students in the alxth grade had very nearly reached, or had exceeded the maxdmum for this test in Soptenber, they were not retested in April. Thls faet naturally linted the posolbilities for average gatn in this elass.

Peading Achlovement Compared to Actual Grade Placonent"

In Mgure 2 the actual grade pleconont for each grade in Septenber Is Indicated by a solld rod bar and in AprLl by an oxtended rod ahaded bar. This shors that each grade achteved on the sverage .8 of a grade or more above the actual. grade placemont in the flinal, test.

The highest achievanent over grade placanent was nade by the fourth grade with 2.7 grades over their h.8 actual grade placonant in Apri1. It will be noted that the achifovenent of this fourth grade was 5.0 In Septenber 1natead of 4.2 as would normally be antlefpatod. With so high a standard alreaty achioved, a substantial increnont in the soven nonths, Soptomber to Apm1, would hardly be expected. Howevor, the students not only matntalned thoir tenth-of-polnt per month, above their alrosdy high acisewenont, but also noro than doubled this to a 2.5 grade gatn, or 15 nonthst galn in 7 nonths-above thetr Sopteraber loval (which alroady was nearly a full grade above the norma)

Iven the flret grade, an unusually bright and mature group achseved an avorage of one full grade ovor thotr actual grade placemont of 1.6. only two flrat grado children falled to roach this lovel.

3 See Definition of Terns, p. 3. 
ACTUAL GRADE PLACEMENT IN SEPTEMBER (.I ABOVE GRADE)

$\square$ ACTUAL GRADE PLACEMENT IN APRIL (.8 ABOVE GRADE)

ACHIEVEMENT IN SEPTEMBER

CA INCREASE IN ACHIEVEMENT IN APRIL

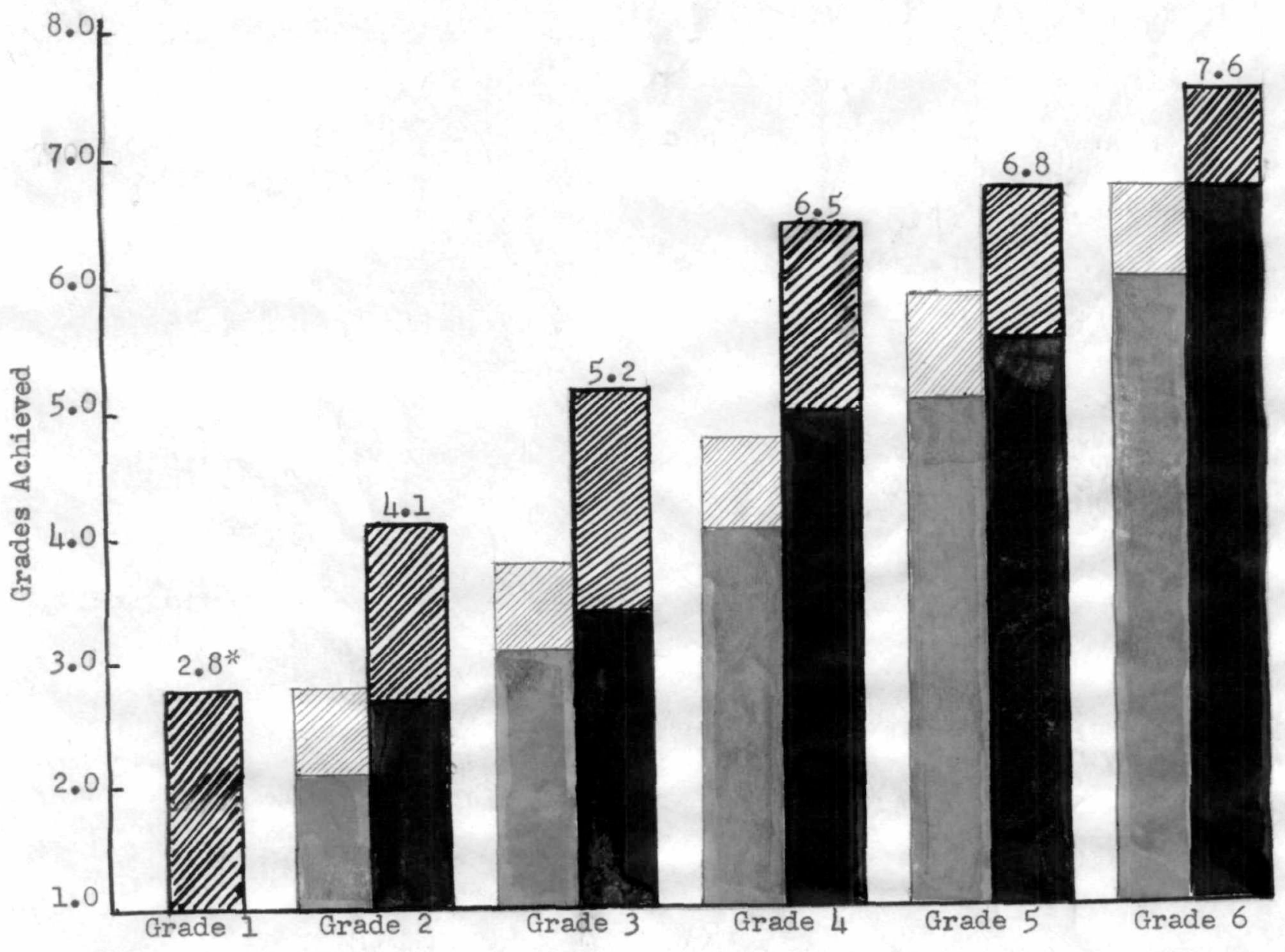

FIGURE 2

AVERAGE READING ACHIEVEMENT BY GRADES

COMPARED TO ACTUAL GRADE PLACEMENT Hै-

* No achievement test was given to the first grade in September. ** See Definitions of Terms. 
Roading Achiovoraent Compared to Reading Capacity

Since one of the goals of the reading progran was to holp overy child read up to his capacity, it was determined by the test results in grades three to six, as nearly as such results can be absolutely valfd, what percentage of students were reading up to their capacity at the tine each test was givon. Figure 3 indicates these results. At the end of Septenber anly 44.5 por cent of 180 chlidren were reading up to their capacity, while the test results at the ond of April showed that 82 per cent were reading up to capacity.

Actual Grace Placenent in Camparisons

It 1s always well to constidor actual grade placenent when studying the resoing achievement of a group. Those students in eacis class who were not able to achleve gracle level varied from al to 3.0 grades or points bolow. That $1 \mathrm{~s}, 12$ one chlid should be in grade 6.8 one month before sohool is out, but actually achleves 5.8 , he is 1.0 polnts below grade placement. Or if another child wore 6.6 at that sane time, he would be .2 of a point belou grade placoment. On this basis it was dectded to total the nurber of points below grade lovel in each grade for the first test in Septeraber and note the improvonent as these pointa were diminished at the second test. This would naturally be a check on the renedial groups since they were made up mostly of those who wore belou grade Level. This is shown in Figure 4 .

The nurber of points below grade placoment as shown by the tost at the last of Septomber is 11lustratod on the chart in black, and the 

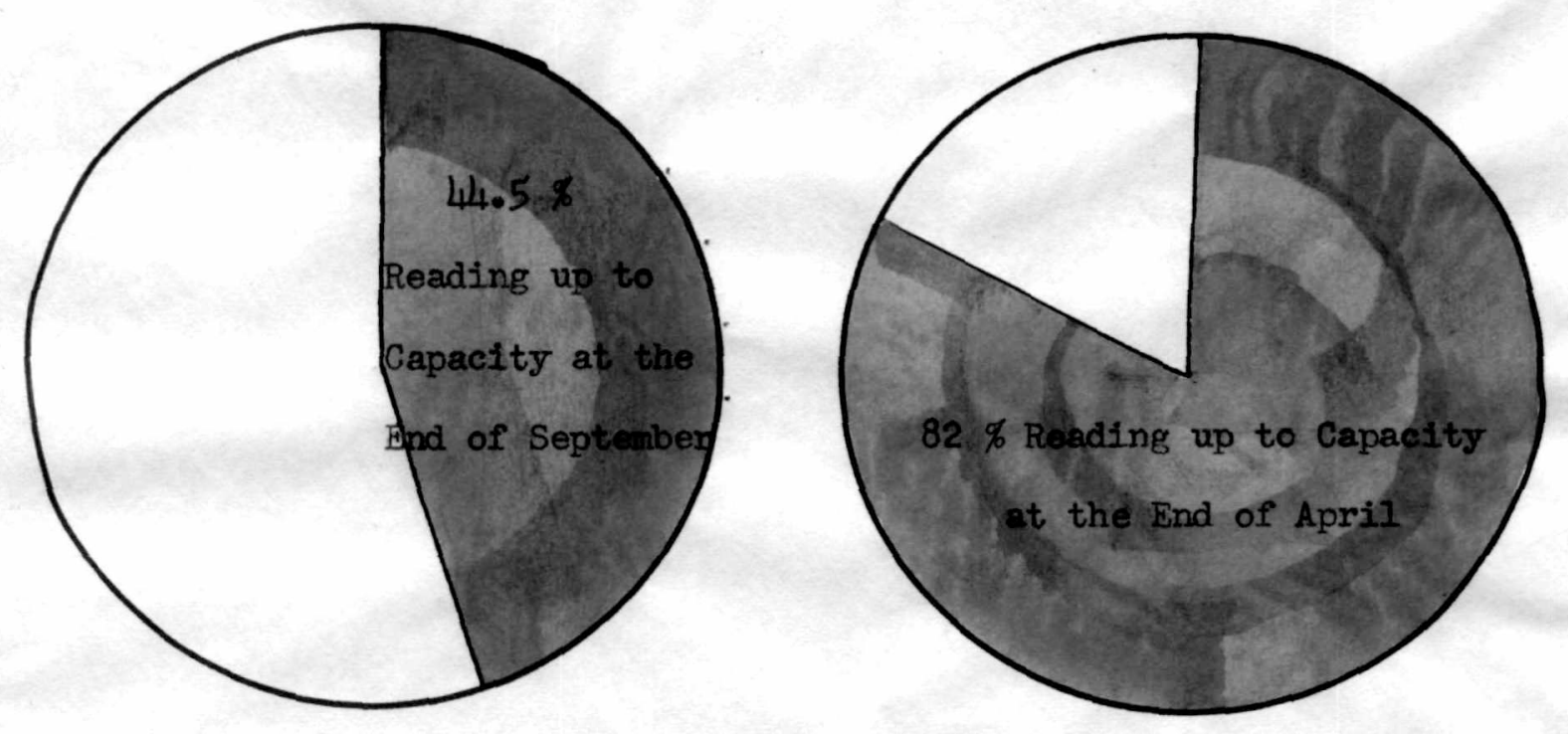

FIGURE 3

PERCENTAGE OF ALL (180) STUDENTS IN GRADES THREE TO SIX READING

UP TO THEIR CAPACITY AT THE END OF SEPTEMBER COMPARED TO THOSE READING

UP TO CAPACITY AT THE END OF APRIL 


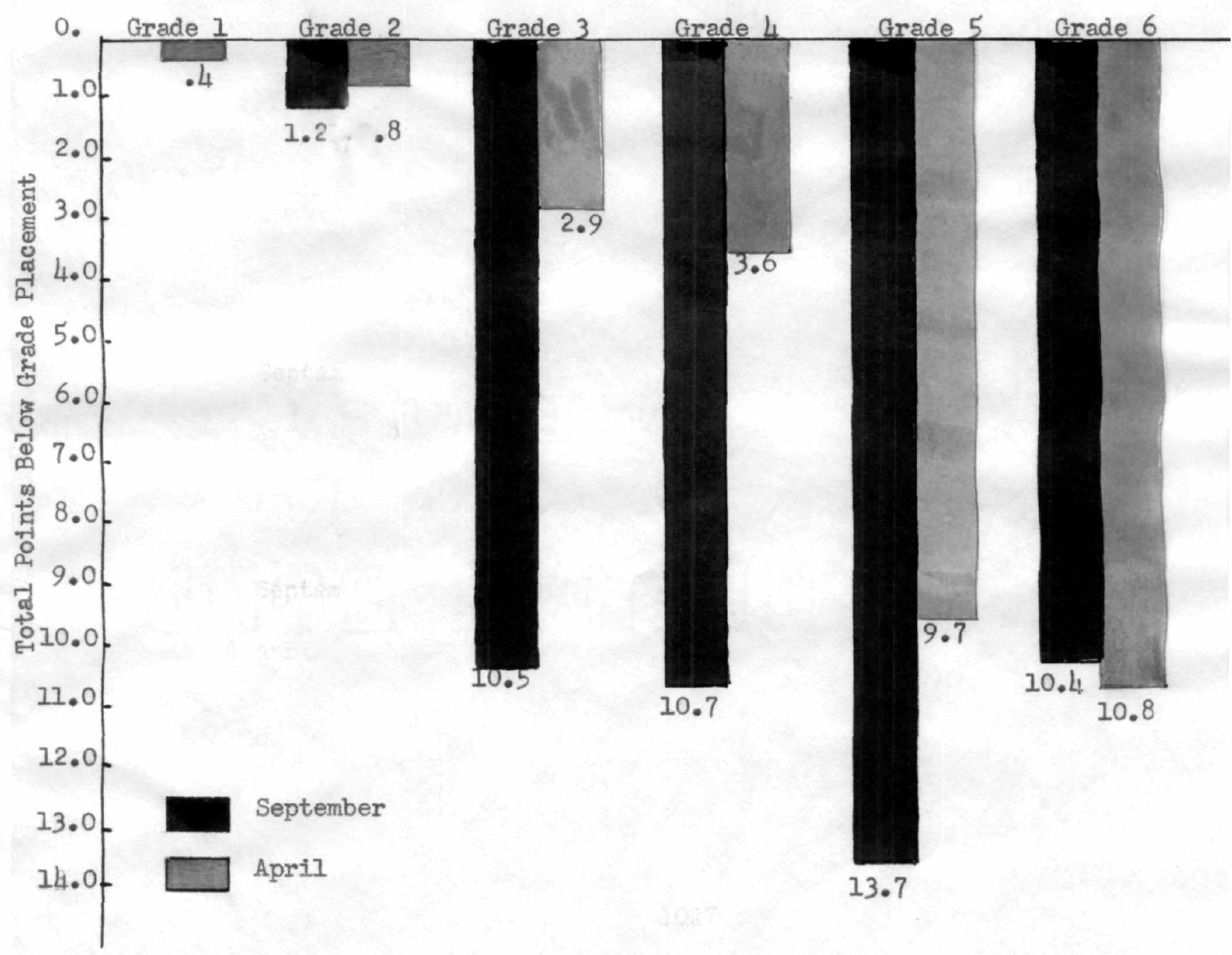

FIGURE 4

COMPARISON OF GRADE PLACEMENT (TOTAL POINTS FOR EACH GRADE) BETWEEN LAST OF SEPTEMBER, 1958, AND LAST OF APRIL, 1959, SHOWING SUMMARY OF THE STUDENTS IN EACH CLASS 


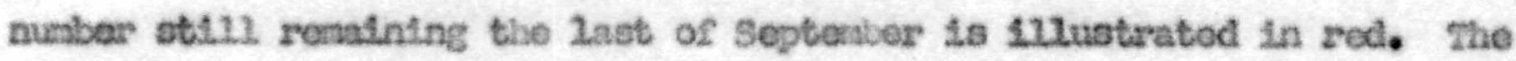
drastle cut in thoso ursanted points in tho third and fourth grades Indicates vory effective teaching of reeding In these grados as well as the possibilsty that students in these grades are nore rocoptive to corrective neasuros and spectal crphasts in roading than in the freth and sisth grados. Though the anpling in this testing progran was not extensive, these rosults may woll moan that the third and fourth grades are the last really good chance to start the avorage chlld on the road to efficlent reading whdle in tho elenentary school.

\section{Cain in rensatal classas}

PAgure 5 whlch shows the gain in achievernont in the ronedlal classes as compared with the gath in the school as a wholo indicates that slon loarners anć onot1onally dlsturbod chsteren who maite up the largor share of the ronodial groups can gonorally keep up with thols on grades if they have spectal attention. The relatively 2 ou galn in the strth grade renedial elasses was 14 troly due to the fact that they recatved less than hale of the Instructional tine that the other elasses recolvod.

\section{Auditory Discrimination}

A soparate experinont in audstory discarintnation with a group of furst gradors is 11 ustrated in Flgare 6. The Murphy-Darrell Diagnostle Reading Roadiness Tost on Oetober 25,1958 ahowed that elght chlidron wore wook in aldteary discrimination. For the next elght wooks they wore gtvan syotematie ear tratining by the ronodial tascier for troaty-five 


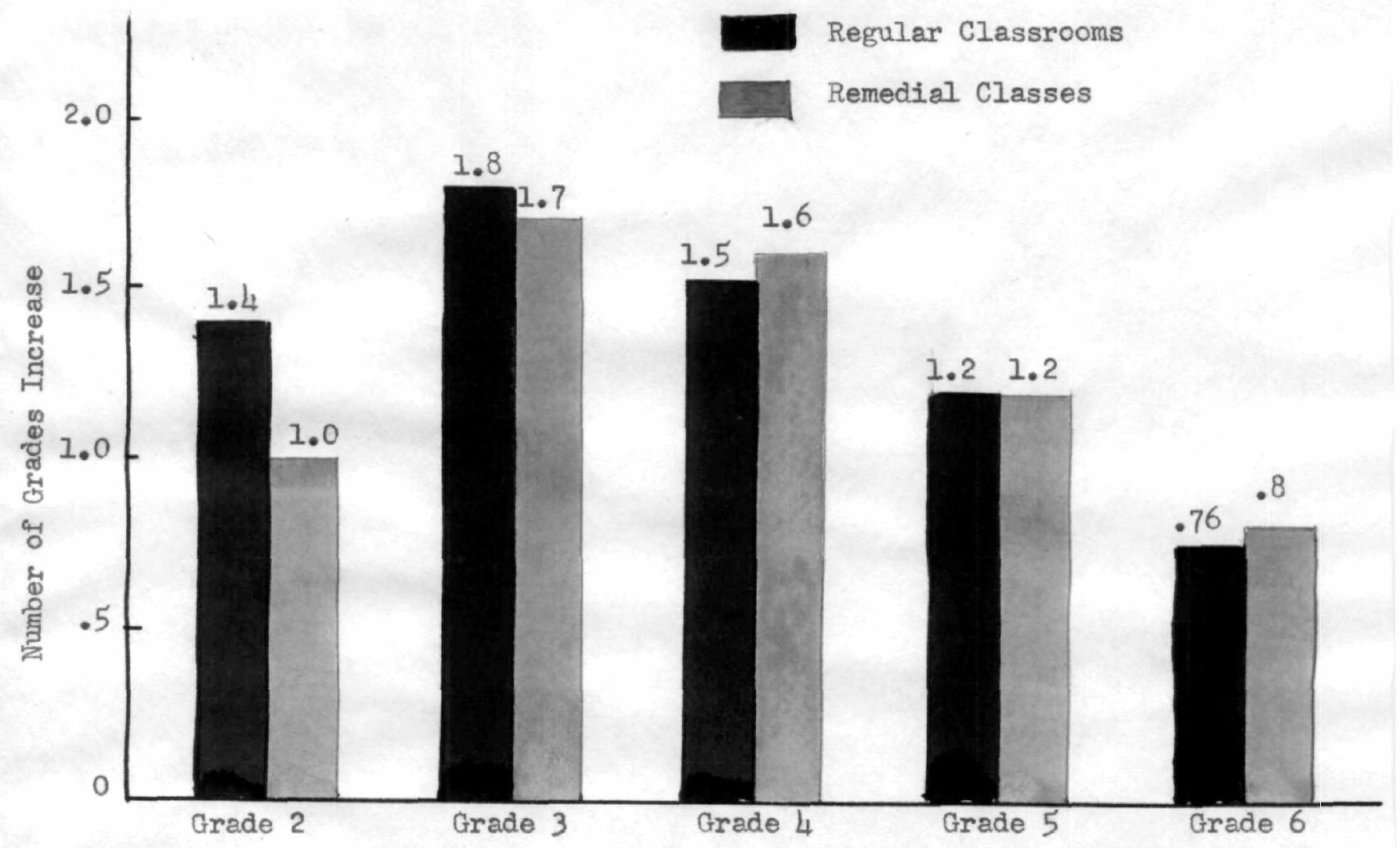

FIGURE 5

GAIN IN READING ACHIEVEMENT IN REGULAR CLASSROOMS COMPARED TO GAIN IN REMEDIAL CLASSES ACCORDING TO GRADES 

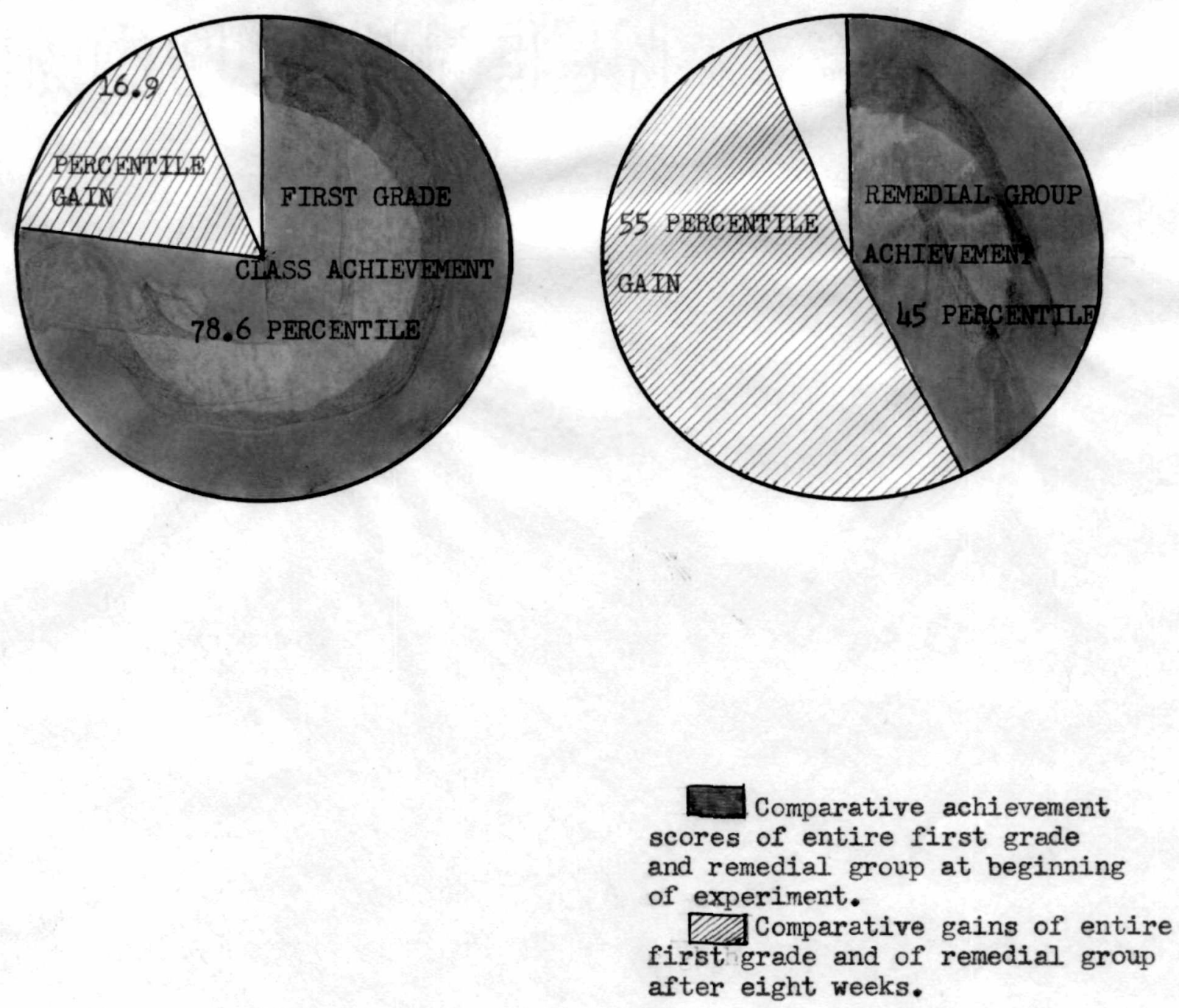

FIGURE 6

EIGHT-WEEK AUDITORY READING READINESS EXPERIMENT 
alnutos a day, four days a weok. The elass as a whole was givon sane tralning by their homaroca toacher. On Decenber 10, 2956 the whale class was roteated and averaged 95 percent120. The renodital group had Irproved 200 per cont and ogualed the avarage of the whole elass. It is quite poastble that these ehuldren would not hare succooded so well in reading 1f theg had not had tasis proparatory tratning.

II. suBnorws ouncours

Parent-toscher Folattonahtpg

There were many outcones whteh could not be objectively measured. It was often acosessod by various teachars that the presence of a roading supervisos in the achool gave thou a featling of conesdence in dolng what they falt was the right thing though parental prossure night bo contrarg. For Inetanes, it was recognised by the supervisor and elassroun teacher that cartaln chuldren would not be expable of Ilnisting all of the presarlbed books for their grade, even though they had boen purchsoed for than at the boginning of the year and even though the toacher folt that the parent would axpect then to bo complotod. Howovor, cartain other school-owned booke were ueed by the chlid which vere on his learning lovel and the more affrteult books ware laft to be flmished at a later tinoprobably at the beginnting of the followling school year. The supervisox was depended upan to support the tenchor in this decialon.

\section{Changes in Clagaroon Asat ganant}

In the case of any rendlag problen the toachor felt that ghe could dopend upon the axport of the suparvisor. When chlildren vere to be 
changed fron one rocm to anothor or if there was a question about where the child should be placod, the supervisor was alveays asked to tast or otharsise chock on the chtld to recomend grade placomant.

\section{Parantel Sactafectlons}

Paronts often indiested enthuslagn and sstiefaetion with the acconplistanents of thoir chtldren in reading. The fact that oach chld was being teeted and supervised by soneone who had made reading a specialty soemed to be vory gratifylag to thene. Aleo when 1.0 was lenoun that romodial work was belng tono, a number of porents requested this special belp

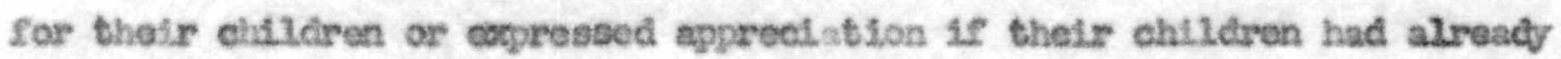
been esaigned to a group. On severnal different occuetons spaalcere or vieltors at the achool mentioned the advantage of this spectal help--indicathing the progressive nature of the progran and complianting the school for this phase of 1te work.

\section{Toachor 10tivation.}

Aftor the second semles of tests were given, sane of the teachers ware so anxilous to get resulto that they chocked the tosts and $r$ eported to tho supervisor before the day vas over. ane corrected her papers durIng a free period and the noon hour and lad the resulte reacly before the afternoon sesolon. A11 vere greatly pleased with the progress made, and voleed the dosire to redouble thetr afforte during the remaining month of the school yoar for those students who vere st111 belor grade lovel. 
Iyportance of Stucient Attitude

One of the $\mathrm{big}$ secrete of the success of the renedtal reading groups was the fact that mombership in then camo to be regarded as a privilege by almost all concerned. The interesting devlees, ganes, and other spocial. mothods used holyed to malntain thio popularity throughout the year. Almost evary fay for the first several months one or more students not in the groups requested to cone until they finally becarne reolgned to the ldes that there was not enough room for any more.

A vary narvous group of threo second grade boys, all with anotional problens caubed by hone sltuatlons, were so inattentive and undisciplined at the beglnning of the school year that they could not concontrate on oven the most stmple rasding gane long enough to onjoy 1t. After patient use of varled neans to bring then sueeess in their work by the middle of the yoar they were begsing to play the gano every day, and had advaneed enough to handle soveral different types of games successfully. Dy the end of the school year they wore able to concentrate on any one project fos the full period of thirty nimutes, whether st was thelr veading worlcbook, a reading gams, phonotic spolling, or Nash card dri11.

Their interest, however, was high from the very first. So anstous were they to cone that thetr hone roon tencher had to cone and get thent twiloe when they slippod out of thoir ow roce too earily. She strietly instructed then not to loave untel. tho clock indented, but she satd that thoy never neoded to be rantinded to cono whether she was busy with other groups or not. 
Spectal Gase No. 1

One especlally interesting case tras an eleven-yoar old American boy from the misat on rield who was placed by age in the flfth grade. His mother indteated that ho would be very shy alnce he had never beon in a regalar achool before, bat his home roon toacher vas not propared for his complete lack of rospones, not evon an "I don't lenose" she soon dectdod not to cause his and hersolf undue eatbarrasment and thereafter did not ask arything fron $\mathrm{him}$. She reportod the altuation. In the routine readIng tests, his achtovenont soore vas so lon that it actually did not roglster on the chart, since the test was for grades three to six, Iris ratIng was left at the vary botton of that test chart-2.2-2-but st no doubt was leas than that, for his oral teoting indicated prompriner level. He had not got loarnod cursivo writing, and his spelling was nll. His roadIng capaclty soore was 5.5.

Be was glvon sone individual help by the renodial. Instructor, and workicod with hle cwn grade's ronodtal group whenever st was posatble. Ho was not a fagt Learnor, but reacted beaut1fukly to Individual, and saall groug work at his Level, rosponding with esthusiasn to the activitios as any normal boy would. He also becane fond of the renedisl tescher, no doubt as a rescucr from his stom of distress, and tried to plaeoe her in evory way he conid.

Stince he was to Leave the sehool, at tho end of pebruary on his way back to the miesion fleld, and since $1 t$ was evident to his rogular clasaroom teacher that his time in hie homeroon could not be effoctively 
utulised (his hone roon toachor sald that he was sothing nore than a "vegotable" there), 1t was dectded about the first of January to bring hin to the renectal rocm full tina. There Le was given a soparate Litlie table and lars for his study. There he hayplily read books oa his Level to make his string of gtars on the chart as Long as posstble. He also did his workbook, spectal phontce exorctsos, and vas called in to participate in as many as three or four differont renectal groups in the day. Has mothes reported that the change "delightod" htr.

On Imerys when the ronodial reading tescher did not ease, he dovotodhy accomplitahed all she had assigned. Orten he case before school. or stayed after school of his own valltion to do more. On many occasilons he would fintsh a book and bring it to the reading teacher with the conment, "Boyl that was realiy a neat book!" and he would roconnend books he had road to others. He seaned not to be self-conschose about thoir balng atmplo books.

A feat days before he was to leave he was glven a Darrell-Sullivan Aehtevenent Teat to compare with the one at the beginning of the year. gre rating by than was 3.4 -a galn of 1.2 In about foux nontho. However, aince 14 was a thed tost, and since he was naturally a slow, deliberate chlle, it did not actually indleato his true reading power. He was able at that thine to road and do fourti cracte workbook matorial accurately and with reaaoneble ease. Fe had practically mastered the essential phonetie and word analysis principles for that grade level, and could attacic alnost any new word aceurately. Just to sce what his word recog- 
nltlon and comprehenston poror might be if not linttod by tine, he was allosed to continue hie test after the score vas determined at the time 14ndt. That time his score was 4.6. Also on a leeldy Reader, tined test, his grade $20 v e l$ vas 4.2 .

However his true accouplishnent was not measurod in grades achitoved but in the fact that he loarned to read and love 1t. Hie first objective when be roached caltrornia was to have hle nothor talce hits to the publie Mtbrary so that he could Itnd sone nore books to road. Hie showed overy 1 ndteation of being woll on his way to normal roading absuty.

Bpecial Case Ho. 2

A boy of the alox, dollborate type in the fourth grade had reachod the place where he aatd openly that he never would be ablo to road and did not care anyway. Aftor renodial, help his teot score shoved a gatin of 2.5 grades in soven nonths. His greatest gain, hovover, was his confldones in his ons roading ablisty. He now volunteore to read orally In his hosaroon and, according to his homeroon teachor, reade corroctly and exprosstvely. Bte workbook work is noat and aceurate, and though he is still slow, his spoed has increased considerably.

Spected Case 푸 3

A cortain third grade boy sooned to flnd socurity in his recding clase which ho apparenthy 2aciced at home. He often cane before sehool or at recoss timo just to say miello" to the reading teachor or to tell sone Incident that happoned at hone or on the way to school. Ile fornod the 
hablt of bringing his lanch vith htm to his class whleh not juet before the noon hour and begsed to stay there to eat lunch. Tater all four boys of his reading group aaked to stay to eat their lunch. All the chllören of the reading groups were the ronodtal teacher's "special. friends:"

Utee of the Blblo and Splmitual outeones

The attractive large-print atbles were a constant source of pleasure for the studenta of the renodtal elsases. The oloven-yoarmold boy fron the atsation fleld vas so dolighted to ftnd that he could actually road the Btble that he arranged with his paronts to buy one each for him and his brothor of that sane kctnd. A favort te activity of his which was shared by two sixth grade boys was alternate verse by verso reading of those Btbles.

Soveral Intoresting Ineldents resulted fron the first fow thas the second gradors used the BLbles. After each chlld was given a Bible, the teacher told thon that 1 t was alwaye best to say a 14t tle prayer before openting then to ask for special holp and underatanding In tholr roading. After the teacher's prayer early in their ronodial experience, the ohildaren wore askod to open their Blbles as noar to the midele as posalble. There thoy found the paulns of David, and the toseher showed how the word pealn 100 lcod and axplatned what 1 meant. Then obe holped then PInd the 23rd Pasm, and they wore thrilled to find that they could "read" 1t. Aetually they knew it from menory. 
The neat cay the firot one to arrive at tho class was a little girl. who begged, "Oh, plaaee, my we road the Blblo rirst again todry? And plase ahow me aggin hen to find what we road jestorday so I can rend it to my torate." Then before the teacher had a chance to mention 1t, one of the children satd, mon't forget we have to have prayer before wo open 1t." When one ensld wae adkod to prav, she sald, rbut I don't know what to say." After bolng rertinded by questitoning that she should be thanitul for and what she wanted Jesus to do for the group, she praved about like thiss mear Jesus, thank you for the nice asble. please help ua to learn to roed it and undorstand 1t. And help us to read your Blble more. For Jesust sake. Anen."

Anotber chtld aslced for the syoctal privtlege of tikting one Btble to her honoroon for the next "Shour and rell Tine" to shor and raad to her cliss. 


\section{CuAPTa vI}

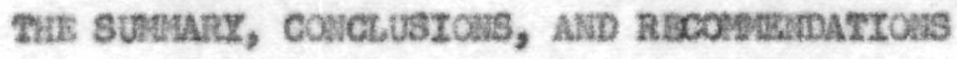

It is the purpose of this chaptos to surwarize tho objectives of the reading progran in the Sevonth-duy Advantist church seinool and the ways in which these objectives wore implenonted through superviston. These have been fora $d$ by the study of church and other odueational Mtorature as well as by the study of currant methods In the sehool of partlchpatlon. Results of the supervisory and ronadlal progran are aleo brienty presonted.

Conckuatons roscied are based on these sano data and reeo mondations Include those for Inprovenont in the sahool of particlpation as well as for furthar study in the fleld of reading.

\section{THE SURARY}

The broad objectives of the reading procran in the seventh-day Adventist church school are as followst

1. To propare the child for the higher sotool in heaven and for sorvice in this world.

2. To teach chuldron to road well arally with propor use of tho volee.

3. To devolop the chlid's lnterest in and desire for good roading, espectally of the atble and the Splrit of prophecy.

4. To toacis the child to understand, organter, and apgratse what he roads, applying the truths of the Buble to his om 14 fe. 
5. To tonch tho slathls the chtld neods to bring success at Ineroabine levels of Atrrtoulty in all subjeets of the curratoulus.

There are a number of spectrie responstbitities for the supervisor in carrging out these objectives:

1. In-service education of the staff.

2. The testing progran.

3. Publie and parent relatione.

4. Naterials of inatruction.

5. Brphasis on reading in all phases of the school progran.

6. Litbrasy boolts.

7. Help for toachers.

8. Use of gutdebooks.

Varlous means, Ineluding an extenstve renedtsl progran, vere used in the school of partiefpation to 1mplemsent those mothods and through then to bring about an Inprovenent in tho ovorwall reading progran of the school. Ilosults of the testing progren indloated stenificant gains in each grade as ahown in the following tablos

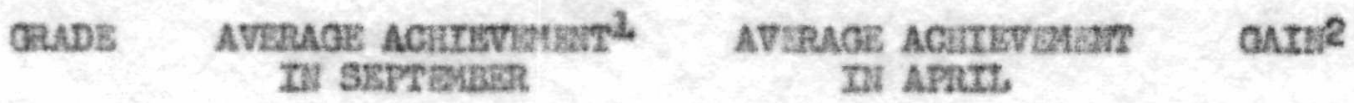

$\begin{array}{llll}\frac{1}{2} & -5 & 2.3 & -1.7 \\ 3 & 2.7 & 4.1 & 1.4 \\ 4 & 3.4 & 5.2 & 1.0 \\ 5 & 5.0 & 6.5 & 2.5 \\ 6 & 5.6 & 6.8 & 1.2 \\ 6.8 & 7.6 & .3\end{array}$

I Nornal adhovement hore would be ..1 over grade--2.1 for second grade, 3.1. for thind grade, ote.

2 worrall expected gain would be .7 . 


\section{II. concuesrous}

There seens to be more agreonent anong authorlties in the resding Ileld concorning objectives, rosponiothlities, and methode in the readIng progran than evor before. This nay be the rosult of untty developed as a defense agalnst outelde attack as voll as the rosult of the trial and error mathoda of the past when the pendulus of all-phonica vs. nophonics and other theories has sung too far, nov brlaging althost all concorned to a more middo-of-the road policy. Frosent rathods are not unaciontifle, however, for they are based on a great deal of research and practical atudy.

Such princtplos as weting phontes only after a reasonable sight vocabutay has bean devoloped, oral reading oaly after stlent reading, allowing for individual differences by different aethods of sroupting, and aastery of one level bofore proceecting to the noot are typlenl of thoso which are in widesprond application at the present tine. The prinelpal differenee between the aethods and objectives of the Seventhday Adveatist elenoatary school rouding progran and thase of any other school is the difforence whith is evtlent in the beste phatlosoping of educations nasoly, to propare the ch13d for otornlty as vol2 as for service to others in thite present 1ffe. This accounts for the great exphast. on the study of the 31Ble and the books of the church in the denointuational schoots.

It Is cleas that the effect of a reading supervisory procrua helps to being about an erphabis on readigg whld would not otherwise 
exclat: (1) The testing procuss 1teolf atimulated in the teachara of the school a consctousnese of reseling wealenesses and an analysts of the type of reading dreficulties present in their studentes (2) zhis In turn motivated then to try to do sonothing construotive about its and (3) the fact that all were worlang togothor in the progran accented this notivathion.

It brought about a closer relationship with paronts, partieularly thoso with ehizeron in the remedtal groups and doveloped in then a groator approciation of what the school was trying to do for their chsldren.

Inprovenent in reading absisty gave a number of chtlden now confidonee in thonselves, botter attitudes toward roadting and learning in general and thus grester securtty in the school and at bonb.

The tenching of ronedilal groups made up largely of anotionally disturbed chidiren lopt them gainting at a nomal, of groater rato which probaply would not hevo boen posotble wh thout spectal attention. This also holped to losep the total school record high.

This struly, though 21 inted in its seope, also strongly Indtested that grester galns can be made at the third and fourth grade levels, both reaectal and othervise, than at any other level.

\section{IIx. RzOAnEunartous}

In addition to the mothods and materials used in this cxporlinent, the following procedures are reconnended: 
1. Increased in-service education of the ataff in groupling and earing for individual needs, including specifle help for teachers whose pupils did not show constatent gains in this experiment.

2. A system of school-owned readers, including as many sets as posstble of supplementary readers on the same levels as the baslc reader, and on lower and higher levels.

3. Increased emphasis on reading instruction as such in the fifth and sixth grades.

4. Increased in-service training for middle-grade teachers in teaching reading techniques for the general student at that level as well as for retarded reeders.

5. Establishment of a centrel library or some method of sharing library books from room to room to inerease avallability to more children.

6. The acquisition of readable, large print Bibles for all children from the seeond grede up.

7. Oreater use of teacher participation in the formulation of the criterla for evaluating and witinately improving their own teaching techniques.

On the besis of experience gained in this experiment, the following recomendations are made for further study:

1. The use of the Bible in the reading class.

2. The training of the volce in the reading class.

3. The possible broader use of oral reading. 
$50 a$

4. The utizization of parents to help in the reading program, especially in pre-school preparation.

5. The relative effect of remedial prograns on the internediate and prinary grades. 
BTBLTOCRAPII 


\section{BIBITOCRAPIY}

\section{Books}

Barr, A. So, Willilan H. Burton, Leo Jo Brueclener. Superviaton. Hew Jorks D. Appleton-Contury Company, Inc., 1938. 981 pp.

A comprahensive treatment of the theory and practsce of superviston by writers of authority in the fleld.

Durrell, Donald D. Improving Reading Instruetion. Hew Yorks World Book Company, 1956. 402 pD.

A practical help for supervisors and teachers of reacing, exphasialing the prevention of difficulties through excellent elassroam tasching.

Nesch, Rudols. Why Johnny Can't Rosd-And What You Can Do About Tt. INen Zork: Hexpar है Brothors, 2955. 2L2 pp.

An attacle upon the present method of the teaching of reading In the Amorican public schools with materlal and instructions for parents to teach their chilld at hosie.

White, Imien G. Chrlotian Bducation. Battle Croek, Iflchigan: International Tract इoctety, $2073.255 \mathrm{pp}$.

An old but basio presentation of the principles of christlan education applicable to current times.

- Counsele to Parents, Teachers, and Students. Mountaln VI

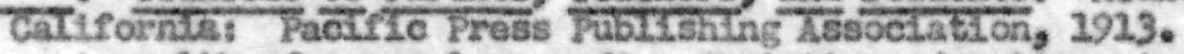

A wealth of counsel regarding Christian education, including the cutiss of parents, guidance for teschers, and practieal instruetion to students.

- gducution. Mountain Viea, Galiforniar Pacifie Press PublishIn Associstion, 1903. 320 pp.

A presontation of the basic principles of Christian education considerod by many authorities to be a masterplece in the fleld.

Whies, Kinball. Supervision for Better Schools. New York: PrenticeHall, Inc., $1950.330 \mathrm{pp}$.

A donocratic approach to a progrem of leadorehip for Ameriean education in a rlowing, readable style. 
White, Blien G. Testianonles for the Church. 10 vols. Mountain Vlew:

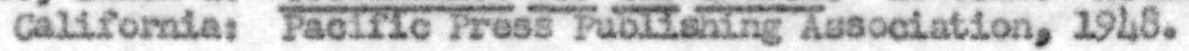

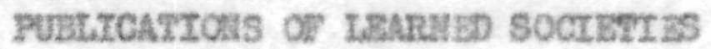

An Adaniniatrator's Handoook on Peading. Xew Zorks Scott, Foresnan and compary, 1956.

Birch, Jack W. Retrleving the Retarded Reader. Bloomlngton, II.: Public school Fublesing congany, $2955.32 \mathrm{pp}$.

Jante Ioarne to Read. (A Handbook for Parents Whose Chsid W1.21 Soon Tearrn to Toad)* Washington, D. Co: Department of Elementary School. Principale and Hationel School Fublic Relations Association, Departmants of the llational Education Association, 195\%. $40 \mathrm{pp}$.

Weeting Special Needs of tho Individual. Child," The Tattonsl Blonentary Prineipal, Mineteenth Yearbook of the Departmont of Dienentary School Frincipals. Washingtons National Bducation Association. vol. $x \pm v, 229-736$, Julv, 2940 .

meading for Today's Children." The Mational Mementary Principal, Thisty-fourth Teartook of the Dopartiont of Btementary Schod Principels. Washington: National glueation Assoclation. Vol. XXXV, 278, Septenber, 2955.

Salisng Into Rosding. (How Your Chald Learns to Read In the Elementary School). Waskington: Departaent of Blemontary School Principals and Notional School Public rolations Association, Departments of the Nlationsl zdueation Association, $1956.40 \mathrm{pp}$.

\section{PERTODTCATS}

Betts, Danett A. mpeading and the Fourth $\mathrm{R}, \mathrm{n}$ glenentary Mnglish, January, $1958, \mathrm{pp} \cdot 28-25$.

Blrch, Jack W. "iscegptLonal Chlldren in Your Regular Classroom," The crade Teacher, 75:34ff., tharch, 1958. 
Dassson, Mildred A. "Whe Role of Oral, Reading in School and Iffe Activities," lemontary Fnglish, Jamuary, 1958, pp. 30-37.

Dickchart, Audray. "Jurealcing the Jock-Steg in Reading," Blenontary 8nglish, January, 1958, pp. 5h-56.

Dolich, E. $V_{0}$ "So Iou Aro Going to be a Renodial Feacher," Ilementary English, January, 1950, pp. 12-10.

Raubinger, Frederick Mo "Irproving Instruction is Your Business," Bducation Digest, 23:11-13, Fobruary, 1958.

Senn, Multon J. E. Connant on MicCall's reacher of the Zear," NoCalls, Harch, 1958, pp. 580-60.

Spache, George D. mesding in Various Carriculum Dields," The Sdueation Digest, 23:47-49, Apr11, 1958.

Tunley, Roul. "Johnny Can Read in Joplin," The Reader's Disest, January, 1950, pp. 42-Lhe

W11t, Mirian $\mathrm{z}_{6}$ "Another Way to Meet Individual Differences," Zlenentary Bnglish, January, 1958, pp. 26-7.

Whtty, Paul Ao "Johnny Could Read Better," The Hation's Schools, 61: Lobli2, January, 1958.

- "Reading for the Potential Loader and Future Solentist," The Wation's Schools, 61:57-9, Februay, 1958.

- "Judging the Resding Prograns" The Nation's Schools, 61.60-1, Apris, 1958.

\section{STARDARDIZID TESTS}

Nurpiav, Helen Avs and Donald D. Durroll. Muryhy-Durrell DLagnostie Readiness Test.

Gates, Arthur. Gates Prinary Roading Test.

Durrell, Donald D., and Eelon Blasr Sulliven. Durrell-Sullivan RoadIng Aehievenent Test.

Durre11, Donald D., and Helea Blair Sullivan. Durrell-Sullivan Beading capacity Test. 
APPIIDTX A 


\section{Apramerx A}

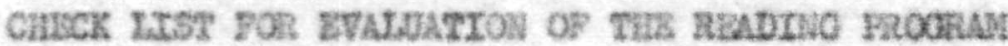

The following check liet was constructed on the basts of the dats gathored by the study of educat1oral 11 terature, both external and church, and observatuon of curvent practiee in the seliool of partscipation. It may be used by the supervisor in svaluating classroan prococtures in resding Instruction or by a teacher who wises to evaluato his om seading progran. A tore detalled check 11 st mitht bo of value for the beachas's use, partheuzarly if he $1 \mathrm{~s}$ inexpertonced or inatoquately tralned.

This check list was organizod in terna of the brosd objectives sat forth in Chapter IJT. A rating plan from a $20 \mathrm{~d}$ of one to a high of flve vas euggested to allcit the appropriate retponse. The total posslble on 22 itens belos wat thorefore 210 :

2. Preparation for sorvice in this world and the higher sehool in heaven.

( ) Do Doos the toacher seen to be aurare of his codegtvon responstbilituas?

() be Does the teacher work together with the parents in carryIng out thels comon purpose?

( ) C. Is there a splritusl emphasis in all teaching?

2. Toaching distdron to read well arally vith proper use of the volce. 
( ) a. Does the teacher have studenta properly propare for oral rosding and wee lt for Ite Intonded purpose, kroplng to a mintrum or elinainating entirely the "easy" nothod of reading round the clasa in routine fashlon?

( ) b. Are all the princtplos of good oral reading boing doveloped fron the plirst grade on ugi?

( ) c. Te proper broathing and use of the volce doveloped?

3. Developing the chuld's Lntereat in and dealre for good readIng, espectally of the Blble and the Spirlt of prophecy.

( ) a. It the setting of the classroom conductve to interest in good reading? (Bulletin board, kibrary table, etc.)

( ) b. Is the peble given its propor place in the reading progran, beglinning with sinple, well-known verses and chapters and procesding to othar aore derfcult passages as aldul parnt ts?

( ) c. Is the realing of the sptrit of prophecy breught in as soon as the child is able to read even anall sections of It?

( ) Does the toacher provide notivation for the reading losson by his mothod of assignnont?

( ) Q. Do baste roaders and 1ibraxy books follow the principle of the proper reading for chlldren who are being propared for heaven?

4. Toaciling the chld to understand, organize, and appralse what he reads, applyting the truthe of the zible to his oun 14fo. 
( ) a. Does the teacher use thought-provolting questions?

( ) b. Does the teacher teach the child to think eloarly by allowing his to toll what he has learned, by writing or giving roports, giving anin 1deas of a paragraph or story, etc.?

5. Teaching sicills the child needs to bring success at increasIng lovols of difficulty in all subjects of the ourrieulum.

( ) a. Does the teacher group students within the classroan according to their absuty? Does he sonotines rearrange groupling to allow for changes in pupdl growth?

( ) b. Does the teacier motivate each student to work to capaeity, thas takling care of both the rotarded roader and the supertor reader?

( ) C. Does the teacher teach roallng stcills necesaary to handle all subjects in the curriculuar?

( ) A. Are the middle and upper grade teachers continuling to teach word analyats and other reading stchuls?

( ) o. Does the teacher make use of avallable materials and books?

( ) 2. Does the taacher doviae moans to appeal to the varled Interests and abilitlos of children?

( ) Bo Doos the teacher male madimum use of test results in grouplag chllderen and choosing books for them? 
( ) h. Does the primary tencher use experitence charte?

( ) 1. Doos tha teacher keep accurate records of the chlldren's rosding progran? 
APPEIDIX B 


\section{APPatDIX B}

\section{LIBT OE MATERTALS}

A nunber of devices used in the renedlel reading clabs were obtained from the following sourees:

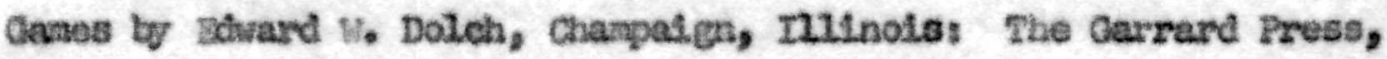
$510-522$ *. HLckory st.

What the Lotters Say

Vowel Lotto

Consonsant Lotto

Croup Sounding came

Take (A Sound Matching Gase)

3ight Phrase Cards

Basie 3 ght vocabulary Cards

The Sylloble dane

Canes from Phonovlaunl Froducts Ine.s, 4803 Wisconsin Avenue, N. W., Washington, D. C., or Zenworthy Educational Service, Inc., Burfalo 1, N. X* Juns or Phonte Rurry

Fhonic Runny (Sets A and B)

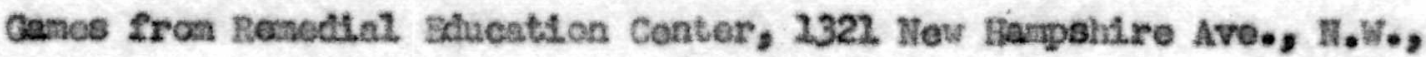
Washington, D. C.

Co Mah (PLrat and Second Sarles)

Vowel Doninoes 
62

The Doghouse cane from Grossot and Dunlap, Inc., 1107 Broadway,

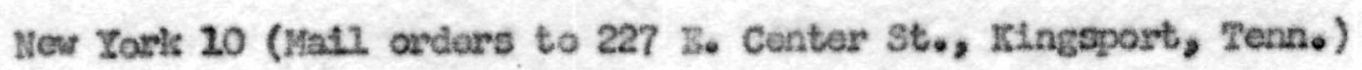

Reading Skatutexts from Charles E. Norri11 Books, Inc., 1300 Alum creek Drive, colluntus 16 , Ohio.

Reading Still Butzdors from The Reader's Digest Educational Service, Inc., Floasantwille, New York.

Continental Publications for any Liquid Duplicator (A Basie Word Analysts Program) Iron the Continental Press, Inc., Balabethtown, Pennsylvania. 